\title{
Big Data Predictive Analytics and Performance: The Role of Transformational Leadership
}

\author{
Collins Ngu Njii ${ }^{* 1}$ Dr. Okechukwu Lawrence Emeagwali ${ }^{2}$ \\ ${ }^{{ }_{1} 1} \mathrm{PhD}$ Student, Department of Business Management, Girne American University; University Drive, Girne-North Cyprus \\ ${ }^{2}$ Lecturer of Strategic Management, Girne American University; University Drive, Girne-North Cyprus \\ Email: collinsngunji@gmail.com, lawrenceemeagwali@gau.edu.tr
}

Article History: Received: 10 January 2021; Revised: 12 February 2021; Accepted: 27 March 2021; Published online: 28 April 2021

\begin{abstract}
The importance of Big Data and Predictive Analytics (BDPA) have been overemphasized in recent years. However previous studies have been so focused on the developed and emerging market economies. The present research investigates this concept within the settings of a developing market economy. Also, the influence of transformational leadership (TL) in the adoption of BDPA as well as its moderation role between BDPA-Operational Performance (OP) nexus hasn't been raised in prior studies. To address this, this study examines the combined effects of Mimetic Pressures (MP) and the Firm's Human Skills (HS) as well as TL in the adoption of BDPA. The present study also examines the impact of TL on OP and its moderating role on the BDPA-OP nexus. Using a pre-tested questionnaire, the research hypothesis was tested on 145 surveys. The results of the empirical study indicate that MP has a positive but insignificant effect on the building and selection of HS and independently the adoption of BDPA is positively and significantly been influenced by both MP and HS. Likewise, BDPA has a positive and significant impact on OP. TL has a positive but insignificant effect in the adoption of BDPA and a negative and insignificant effect on OP. Also, the moderating effect of TL in the BDPA-OP nexus was found to be positive and seemingly significant.
\end{abstract}

Keywords: Big Data and Predictive Analytics, Mimetic Pressures, Human Skills, Transformational Leadership, Operational Performance.

\section{INTRODUCTION}

To support decision making, some organizations make use of BDPA broadly described as an organizational capability to rapidly process voluminous and multiplicities of data sources to gain relevant insights that will enable it to gain competitive advantage (Dubey et al., 2019; Srinivasan \& Swink, 2018, Gupta and George, 2016). Saggy and Jain, (2018) refers to big data as gigantic and actual data sets which regular data processing techniques can't process. This is because big data requires more modern techniques to apprehend occurrences (Gupta \& George, 2016; Jia et al., 2016; Khan \& Vorley, 2017). In the ongoing years, Business Analytics (BA) research has been of great concern and most managers continuously place BA related activities at the top of their agendas and dispense a significant amount of their finances for its applications (Columbus, 2014; Cosic, Shanks \& Maynord, 2015). Dubey et al., (2019) highlight that the formation of resources necessary for the adoption of predictive analytics to improve on the firm's performance can be explained by external influences such as MP. Sharma, Mithas and Kankanhalli, (2014) postulates that the success and survival of an organization is enormously influenced by its ability to embrace dynamics in the external environment. Therefore as a standard in decision making and the improvement of the organization's competitiveness, managers must be very much educated regarding present occurrences in the business environment. Therefore while effectively managing the firm's resources such as its human resources is very essential, an efficient coordination with external forces adequately balances every component to guarantee the creation of customer value, sustainable competitive advantage and an amelioration of the firm's operative efficiency (Sirmon, Hitt \& Ireland, 2007). The effects of TL in the adoption of BDPA and as well as its moderating effects between BDPA - OP nexus is been examined. According to Vaccaro et al., (2012) leadership adds to the formation of distinctive procedures and practices and has an important role in improving organizational performance (Aktas, Cicek \& Kiyak, 2011; Lado \& Wilson, 1994; Schein, 2004) such as helping employees to identify themselves with the organization's mission and goals (Vaccaro et al., 2012). BA and its various tiers (data acquisition and processing, descriptive analytics, predictive analytics and prescriptive analytics) in relation to the firm's performance have been widely studied (Bag et al., 2020; Dubey et al., 2019; Aydiner et al., 2019; Wamba, Akter \& De Bourmont, 2019; Nam, Lee \& Lee, 2019; Whitelock, 2018; Raguseo \& Vitari, 2018; Wamba et al., 2017; Gunesekaran et al., 2017; Akter et al., 2016). Building only from the premises of the Resource-Based Theory (RBT), Aydiner and his co-authors examined the link between the adoption of BA and the performance of a sample of Turkish firms. Dubey and his co-authors examined the link between BDPA on the performance of manufacturing firms from the perspectives of the institutional theory and the RBT. However, for purposes of investigating their study's external validity, Dubey and his co-authors recommended extant studies to consider other industry sectors (Dubey et al., 2019). The uniqueness of 
this study is that this phenomenon is examined from an institutional theory perspective (Aydiner et al., 2019) as well following Duby et al., (2019) at a composite level. Also, this is the first study to examine the moderating effects of TL in the BDPA-OP nexus. Apte, Dietrich and Fleming, (2012) describes BDPA as a transformational technology that comes along with enormous benefits for the firm. Most recent studies have either been carried out within the milieu of a developed or an emerging market economy (Barr-Pulliam, Brown-Liburd \& Sanderson, 2020; Bag et al., 2020; BarrPulliam et al., 2020; Raguseo, Vitari \& Pigni, 2020; Vitari \& Raguseo,2020; Wamba, Akter \& De Bourmont, 2019; Nam, Lee \& Lee, 2019; Walker \& Brown- Liburd, 2019, Dubey et al., 2019; Aydiner et al., 2019; Raguseo \& Vitari, 2018; Cruz-Jesus et al., 2018; Whitelock, 2018). Parts of Africa is characterized by developing markets and institutions here have been highly criticized for their lack of transformation (Herbst \& Garg, 2017). Another peculiarity of the present study is that it investigates the concept of BDPA within the settings of a developing market economy such as Cameroon. Hence, the present research aims at enriching the current literature by filling the above mentioned research gaps. The rest of the paper is organized thus: literature review, conceptual framework and model, next is the data collection method, data analysis procedure and results of model testing. Followed by the discussion of results, conclusion, implications, limitations and directions for further research.

\section{LITERATURE REVIEW}

The conceptual bases of this research "Big Data and Predictive Analytics and Performance", brings together the institutional theory and RBT and is formed by efficiently combining the constructs hereinafter: mimetic pressures (MP), human skills (HS), big data and predictive analytics (BDPA), transformational leadership (TL) and operational performance (OP).

\subsection{Institutional theory}

The institutional theory came in to existence as another approach that analyzes how firms react amidst external pressures. As indicated by Oliver (1997), there exists a high probability that various societal elements influence organizational choices. As such, the institutional theory seeks to explain the mutual attributes amongst organizations as well as organizational level changes (Greenwood \& Hinings, 1996). Liu and his co-authors citing the case of family enterprises posits that their performance is predominated by institutional effects (Liu, Yang \& Zhang, 2012). Unlike the institutional theory, other theories lay emphasizes on efficiency as the motive of organizational action. However, organizations don't work in a vacuum and they continually manage various external influences that cause them to embrace isomorphism (Berthod, 2011). Lin and Sheu (2012) defines isomorphism as an obliging process whereby organizations are influenced to resemble one another within a similar environmental condition. Amongst the various forms of institutional isomorphisms is mimetic isomorphism caused by MP. Mizruchi and Fein (1999) describes mimetic pressures (MP) as pressures that occur when organizations model themselves after others which they deem more successful. This usually occurs amid an uncertain environment with an ailing understood technology (DiMaggio \& Powell, 1983). Gold et al., (2010) touted that big data analytics (BDA) standards continue to be ambiguous whereas investments are irreversible. Therefore, as a result of intense competition, it is important for firms to mimick others that have been successful in adopting this technology. Along the same line John et al., (2001) postulated that when firms are faced with issues of uncertainties, they may just simply observe the practices of standard competitors to expand their understanding of a given phenomenon. MP largely affects the firm's intent of adopting innovations such as BDPA (Ketokivi \& Schroeder, 2004; Zsidisin, Melnyk \& Ragatz, 2005).

\subsection{The Resource-Based Theory (RBT)}

The RBT is a fundamental concept in strategic management and management information systems (MIS) aimed at understanding resource-performance link. It explains how the assembling of strategic resources leads to competitive advantage (Dubey et al., 2019). According to Gu, Jitpaipoon and Yang (2017), the resource-based theory enables Information System (IS) resources to be identified, categorized and evaluated for competitive advantage and performance. According to Gaya (2016), in service firms, the acquisition of resources is the first step in the value creation process. Capabilities determine the organization's ability to utilize its resources (Amit \& Scheomaker, 1993). Therefore, the best method of utilizing resources is very determinant in the attainment of competitive advantage. However, for this to be achievable capabilities must meet VRIN (valuable, rare, imperfectly imitable and non-substitutable) requirements (Barney, 1991). HS is an organizational resource that must be effectively utilized to build the firm's BDPA capability (Gunasekaran et al., 2017). Kornacka (2001) asserts that recent IT innovations require organizational as well as human capital to be successful. Technical and managerial skills are two determining sub-dimensions of human skills (Chae, Koh \& Prybutok, 2014; Gupta \& George, 2016). Technical big data skills is the expertise required to apply innovative technologies for mining out information from big data. Hence, as a result of the newness of big data and its related skills, firms that employ employees who have these skills are likely to out-compete their competitors (Gupta \& George, 2016). Some examples of technical big data skills include competencies in machine learning, data extraction, data cleaning, statistical analysis, and knowledge of programming paradigms (Teece et al., 1997). Big data managerial skills are the abilities of managers to apply knowledge extracted by the technical staffs to achieve desired objectives (Gupta and George, 2016). Contrary to technical skills that may be spread amongst people working in the same or different 
institutions, managerial skills are firm specific and developed over time by the firm's employees as a result of interactions amongst people working in the same or different units (Carr, 2003; Bharadwaj, 2000).

\subsection{Big Data And Predictive Analytics (BDPA)}

In recent years, BDPA has surface to be an important practice that positively influences the competitive position of business organizations. Analytics applications are increasingly being effectively incorporated together with transactional systems and this allows data to be analyzed to such an extent that the results quickly reflects in business activities (Kohvani, et al., 2002). Aydiner and his co-authors write that amongst the tiers for the effective adoption of BA is DACQ (data acquisition and processing) and PRED (predictive analytics). DACQ is one of the most important enablers of BA (Aydiner et al., 2019) because it is a challenging phase that entails the creation of the data upon which other analytics activities such as predictive maintenance is possible (Sharma, 2017). Sharda et al., (2016) highlight that DACQ extricates data from systems as well as from external sources and later on condenses and load them in to other applications. Some example of DACQ-related IS applications are information propagation, data warehousing, data capturing, and document management systems (Aydiner et al., 2019). PRED transforms big data in to valuable business information by utilizing mathematical algorithms and programming to analyze past performance to predict future happening (Demirkan and Delen, 2013). Wang et al., (2016) postulate that BA supplements strategic management by initiating predictive insights into strategy execution processes. Examples of PRED applications include data mining, market intelligence, decision support systems and investment intelligence (Aydiner et al., 2019). Previous reviews have stated that BDPA has a big impact in any industry and it is expected for organizations that determine their needs utilizing BDPA to out-perform competitors as they constantly utilize them in all key business decisions such as costing, pricing and advertising (LaValle,2010; Chen, Chiang \& Storey, 2012; Dubey et al., 2019, Bag et al., 2020; Evans \& Lindner (2012).

\subsection{Transformational Leadership (TL)}

As confirmed from prior studies, Pounder (2008) postulates that leadership styles are positively related to organizational outcomes. According to Robbins (2003), TL is defined as a style of leadership whereby leaders inspire their followers to exceed self-interest to work towards the accomplishment of organizational goals. In recent years, TL has been studied with several other organizational constructs such as innovation, performance and organizational effectiveness (Xenikou \& Simosi, 2006; Ke \& Wei, 2008; James \& De Lourdes Mechado, 2006). Montgomery (2008) asserts that leadership is inevitable in strategy reformulation therefore strategic leadership expantiates on the importance of merging the two concepts strategy and leadership. As cited in Jooste and Fourie (2009), Hitt, Ireland and Hoskisson (2007) defines strategic leadership as "the leader's ability to anticipate, envision and maintain flexibility and to empower others to create strategic change as necessary". Change is a basic characteristic of TL that is achievable by persuading employees in the direction of the company's vision and mission to improve performance (Robbins, 2003; Burns, 2004; Alqatawenh, 2018). TL consist of four dimensions: idealized influence (the point at which the TL is been emulated by followers as a result of the respect, trust and admiration for him (Barbuto \& Burbach, 2006) ); inspirational motivation (TL's capability of creating a vision for the organization that influences employees to perform a significant role (Alqatawenh (2018).); intellectual stimulation (ability to inspire thoughts and imagination (Bass, 1985)) and individualized consideration (taking in consideration followers individualism to link their priorities with that of the organization (Bass \& Avolio, 1994)). TL's role in the adoption of BDPA and BDPA-OP nexus which is within the scope of the present research brings to bear the leaders' ability to effectively transform their organizations.

\subsection{Operational Performance (OP)}

According to Voss, Åhlström, and Blackmon (1997), Operational performance refers to the measurable outcomes of an organization's processes. Processes here refers to the chain of actions as well as decisions that are required to effectively execute an organization's activities (Dumas et al., 2013). This term has become more relevant in strategic management and IS as organizations are continuously been challenged to realize desired results. Mithas, Ramasubbu and Sambamurthy (2011) opined that nowadays competitive advantage could be achieved by appropriately managing the firm's processes with the objective of improving operational performance. Previous scholars have opined that in order to put in place an effective organizational process management system, the performance of current processes must first of all be assessed (Aguilar-Savén, 2004; Bisogno et al., 2016; McCormack et al., 2009). Robson (2004), asserts that measuring is a common and important practice that enables organizations to improve on the overall performance of their processes by putting in place a reliable feedback control system for employees to always evaluate, select and take action. Van Looy and Shafagatova (2016) reiterates that the measurement criterion has to be linked to the organization's strategies since performance choices entirely depend on each organization (Van Looy \& Shafagatova, 2016). In response to the demand for more realistic methods of process analysis, substantial measures such as productivity, responsiveness to customers' request, economies of scale and scope, market share, etc. do define each perspective of operational performance (Bolsinger et al., 2015; Van Looy \& Shafagatova, 2016). 


\section{CONCEPTUAL FRAMEWORK}

Peng et al., (2009) postulate that according to the Institutional theory, firms do not exist in a vacuum. So, there is a tendency for organizational practices such as building and selecting HS to be influenced by external pressures- MP (Tatoglu, Glaister and Demirbag, 2016). Therefore as postulated by Dubey et al., (2019), the Institutional theory and the RBT when combined together could explain how analytics capabilities such as BDPA is created to enhance performance; and this relationship could be strengthened by Transformational leadership. Fig 1 shows the links between each of the theses variables is discussed in the following sub-sections:

\subsection{Mimetic Pressures (MP), Human Skills (HS) and Big Data And Predictive Analytics (BDPA)}

Demirbag et al., (2017) postulate that the institutional theory is an alternative perspective that examines organizational reactions in regards to external pressures. It explains how strategies and decision making within the organization are affected by external pressures (Glover et al., 2014). Lin and Sheu (2012) further highlight that to promote their legitimacy, organizations tend to mimic others, especially from the same sector when they deem them to be more successful. Bag et al., (2020) advances that as a result of competitive activities, firms are pressurized to adopt training methods aimed at upgrading their employees in order not to be out beaten by competition. Likewise, in matters of recruitment and selection processes (Schuler,1995). A case in point is from the recent works of Dubey et al., (2019) while examining the influence of BDPA on manufacturing performance came to conclude that institutional MP has a significant positive impact on the selection of the firm's HS. They directly influence the selection of HS without which capabilities are can't built. The perceived success of competing firms from the application of BA will positively influence others to its adoption (CruzJesus, Oliveira \& Naranjo, 2018). Thus these pressures are strategic antecedents for the adoption of BDPA. Gupta and George, (2016) advanced that human resources are inevitable in the creation of capabilities. BDPA is an organizational capability that explains how performance can be improved by BDPA (Aydiner et al.,2019; Dubey et al., 2019; Gunasekaran et al., 2016; Gupta \& George, 2016).

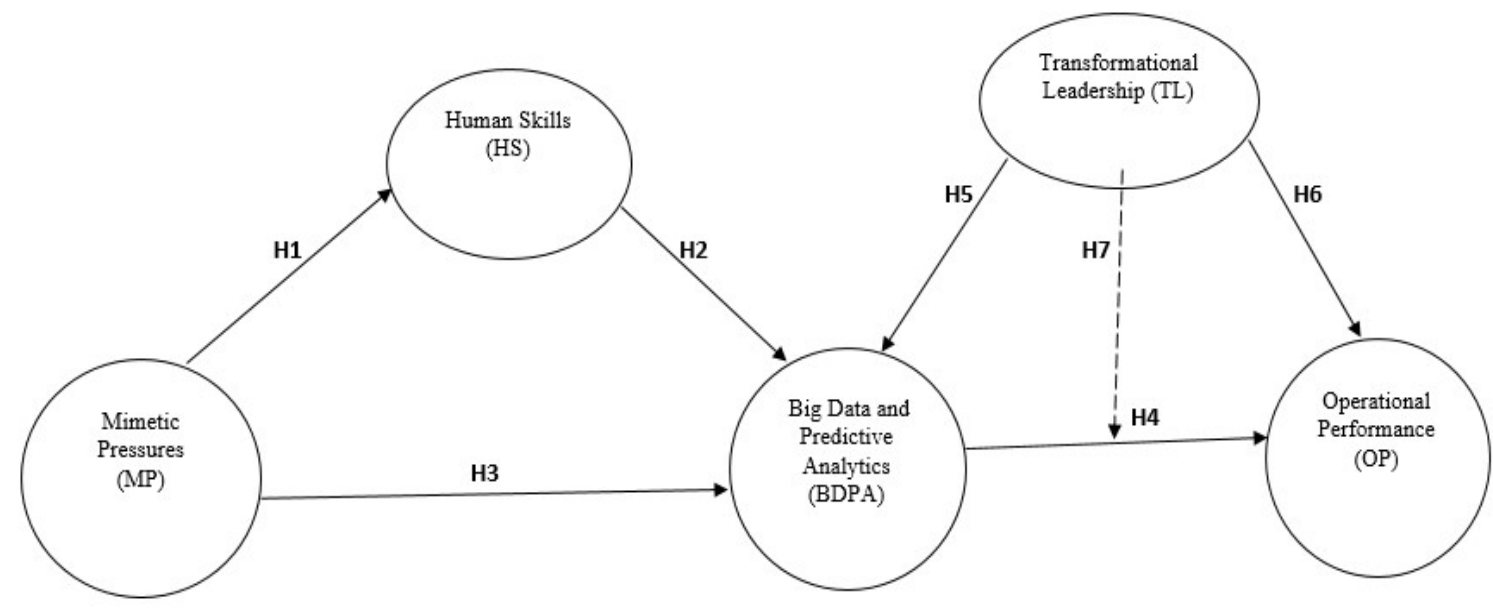

Fig 1: Conceptual framework

HS such as big data technical and managerial skilled employees has been noted as a source of competitive advantage for the firm (McAfee et al., 2012) as they enable it to adequately responds to the increasing demands of a data-driven world. Therefore, drawing evidence from the above review the following hypothesis is advanced:

H1: MP has a significant positive impact in the building and selection of $\mathrm{HS}$

H2: HS has a significant positive impact in the Adoption BDPA

H3: MP has a significant positive impact in the Adoption BDPA

\subsection{Big Data and Predictive Analytics (BDPA) and Operational Performance (OP)}

It has been empirically tested that information system (IS) positively and significantly affect OP (Bayraktar et al., 2009). Whitelock (2018) argues that the firm has a high probability to achieve improved operational performance by implementing sophisticated analytics techniques. Previous studies have enormously tried to link BA/BDA/BDPA and organizational performance (Elbashir et al., 2008; Cosic et al., 2015; Troilio et al., 2016; Ramanathan et al., 2017; Dubey et al., 2019; Aydiner et al., 2019; Larson \& Chang; 2016) and have found that this technology possesses the potentials of improving performance (Aydiner et al., 2019; Dubey et al., 2019; Troilio et al., 2019; Larson \& Chang, 2016). Aydiner et al., (2019) posit that BA supports the organization's objective of achieving competitive advantage by enhancing the performance of processes for improved customer satisfaction. Along the same line, Gunasekaran et al., (2016) basing on empirical results argue that knowledge obtained as a result of BDPA capabilities has been utilized to ameliorate the supply chain performance of organizations. Based on empirical results, Dubey et al., (2019) equally found that the operational performance of manufacturing firms is positively being influenced by BDPA. 
H4: Big Data and Predictive Analytics (BDPA) have a significant positive impact on the firm's operational performance (OP).

\subsection{The Roles of Transformational Leadership (TL)}

The role of leadership in the firm appropriately evolves and in tandem (Schein, 2004). Transformational leaders are core actors in organizational change and performance. According to Colbert et al., (2008), within the organizational framework, leaders facilitates innovativeness and enhances performance. Gago-Areces (2017) posits that as these novel technologies are incorporated in the firm's IT systems, Transformational leadership is necessary in utilizing such innovation in order to address multiple issues confronted by organizations by influencing the labour force (Gago-Areces, 2017; Cleepkasova Macalint. Apte, Dietrich and Fleming, (2012) describes BDPA as a transformational technology that comes along with substantial quantifiable results since it provides for the businesses a competitive edge over their rivals. Baharuden, Isaac and Ameen (2019), while analyzing the role of TL as a factor that influences the intentions of SMEs executives towards Big Data Analysis (BDA) learning in Malaysia found that TL facilitates BDA learning intentions on performance. TL also increases identity between supervisors and followers and this makes employees develop confidence in order to perform beyond expectation (Arif \& Akram, 2018). Lee (2008) further postulates that TL is connected to innovative capabilities which encourage employees to surpass self-interest towards the organization's progress. Also, organizations that respond to changes in the environment by being flexible to innovation easily develop capabilities that enable them to attain higher performance levels (Montes, Moreno and Fernandez, 2004). Therefore, in such business contexts, TL is required in order for the firm to achieve the desired level of performance (Judge and Piccolo, 2004).

H5: Transformational leadership has a significant positive impact in the adoption of Big Data and Predictive Analytics. H6: Transformational leadership has a significant positive impact on Operational Performance.

H7: Transformational leadership will further strengthen the impact of Big Data and Predictive Analytics on the firm's operational performance.

\section{METHODOLOGY}

\subsection{Survey instrument}

This study applies a cross-sectional research design adopting descriptive analytical research in which both selfadministered and e-mailed questionnaires were utilized in order to collect data on five constructs (Mimetic Pressures (MP), Human Skills (HS), Transformational Leadership (TL), Big Data and Predictive Analytics (BDPA) and Operational performance (OP)). Questionnaire items originally developed in English and later on translated to French were all adapted from existing literature and instruments. Items that measured MP and HS were adapted from the works of Gupta and George (2016). Measurement items for HS were both technical and managerial skills. Items that measured TL pertaining to vision articulation, fostering shared group goals, performance confidence and autonomy were adopted from the works of Zhang and Bartol, (2010); Luque et al., (2008) and Rubin, Munz, \& Bommer, (2005). BDPA was measured by items adopted from Zwass (1998), Alter (2002), Sharda, Delen \& Turban (2016), Laudon \& Laudon (2013) and Hindle and Vidgen (2018) and OP from Mahmood and Soon (1991); Elbashir et al. (2008), Bayraktar et al. (2009), Mclaren et al. (2011), Mithas et al. (2011) and Luo, Fan and Zhang (2012). All constructs were measured on a five-point Likert scale ranging from 1 ("strongly disagree") to 5 ("strongly agree") and 1 ("never") to 5 ("always").

Control Variable

The unique characteristics of the firm were accounted for by the control variable industry category. Dummy variables were used in order to distinguish the various industrial sectors (banks, IT, construction, wholesale, telecommunication, textile, F\&B, health, others) (see fig. 2). After translating the questionnaire to French, it was then translated back into English in order to verify the correctness in translation. Prior to administering the questionnaires, an endorsement was obtained from my affiliate university's research ethical council to ensure the non-violation of ethical standards. The measurement of the study constructs, the wording of the questions and their sources are replicated in Appendix A and B.

\subsection{Sample and data collection}

The sampling frame was formed from the database of the Employers Association of Cameroon popularly known by its French acronym as "Groupement Inter-patronal du Cameroun (GICAM)" which is the largest employers association in Cameroon with 350 member enterprises from different industries such as banking and insurance, telecommunications, food and beverage, textile, IT, health services, construction, etc. Using the convenience sampling technique, 466 questionnaires were distributed to two categories of respondents (managers and non-management staff) from various firms of different industries. This for the purpose of obtaining a high level of external validity of the study's results following (Dubey et al, 2019). Following Aydiner et al., (2019), the focus on large and medium-sized enterprises was due to the fact that they will be in possession of the resources required for their investments. The choice of the convenience sampling technique in the present research is justified by the difficulties encountered in having access to various respondents. Managers were the targetted respondents as a result of their high involvement in decision making. However, respondents were selected amongst non-management employees to collect data related to the single construct TL which measures Transformational leadership perceptions in the various organizations. The research questionnaires were distributed from the first week of November 2019 and by May 2020 ending a cumulative total of 145 questionnaires 
were returned thus a response rate of $31.1 \%$. A summary of the characteristics of the sample including respondents' (firm-level) demographic information is shown in Table 1.

Non-response bias

Non-response bias was tested following Chen and Paulraj, (2004) by performing the Student's t-tests on early and late waves of respondents on all the descriptive variables. Early respondents are those that returned their responses within the first three months and late respondents those whose responses were received later on. From the t-test results, it was found that with the exception of gender and years of operation for the management category who had significant differences between early respondents and late respondents (i.e. $p<0.05$ ), we found no significant difference for all the other variables (i.e. $\mathrm{p}>0.05$ ). Therefore the potentials of non-response bias is very negligible.

Table 1: Characteristics of the sample

\begin{tabular}{|c|c|c|c|c|c|c|c|}
\hline \multicolumn{8}{|c|}{ Descriptive Report of Respondents } \\
\hline \multicolumn{2}{|c|}{ Managers } & \multicolumn{2}{|c|}{ Total } & \multicolumn{2}{|c|}{ Early Respondents } & \multicolumn{2}{|c|}{ Late Respondents } \\
\hline Demographic Variables & Categories & $\mathbf{N}$ & $\%$ & $\mathbf{N}$ & $\%$ & $\mathbf{N}$ & $\%$ \\
\hline \multirow[t]{2}{*}{ Gender } & Male & 40 & 57.14 & 35 & 62.5 & 5 & 35.7 \\
\hline & Female & 30 & 42.86 & 21 & 37.5 & 9 & 64.3 \\
\hline \multirow[t]{4}{*}{ Age } & $<30$ years & 17 & 24.28 & 11 & 19.64 & 6 & 42.86 \\
\hline & $31-40$ years & 32 & 45.72 & 31 & 55.36 & 1 & 7.14 \\
\hline & $41-50$ years & 19 & 27.14 & 12 & 21.43 & 7 & 50 \\
\hline & $>50$ years & 2 & 2.86 & 2 & 3.57 & 0 & 0 \\
\hline \multirow[t]{3}{*}{ Education } & Bachelor & 5 & 35.71 & 25 & 44.64 & 0 & 0 \\
\hline & Masters & 44 & 62.86 & 30 & 53.57 & 0 & 0 \\
\hline & $\mathrm{PhD}$ & 1 & 1.43 & 1 & 1.79 & 14 & 100 \\
\hline \multirow[t]{5}{*}{ Position } & CEO & 1 & 1.43 & 1 & 1.79 & 0 & 0 \\
\hline & Chairman & 1 & 1.43 & 1 & 1.79 & 0 & 0 \\
\hline & Senior manager & 7 & 10 & 6 & 10.71 & 1 & 7.14 \\
\hline & Executive manager & 6 & 8.57 & 6 & 10.71 & 0 & 0 \\
\hline & Middle managers & 55 & 78.57 & 42 & 75 & 13 & 92.86 \\
\hline \multirow{5}{*}{ Number of employees } & $<250$ & 16 & 22.86 & 16 & 28.57 & 0 & 0 \\
\hline & $251-500$ & 13 & 18.55 & 9 & 16.07 & 4 & 28.57 \\
\hline & $501-1000$ & 17 & 24.29 & 7 & 12.5 & 10 & 71.43 \\
\hline & $1001-5000$ & 21 & 30 & 21 & 37.5 & 0 & 0 \\
\hline & $>5000$ & 3 & 4.29 & 3 & 5.36 & 0 & 0 \\
\hline \multirow[t]{5}{*}{ Years of operation } & $<5$ years & 18 & 25.71 & 14 & 25 & 4 & 28.57 \\
\hline & $5-10$ years & 30 & 42.86 & 21 & 37.5 & 9 & 64.29 \\
\hline & $11-30$ years & 22 & 31.43 & 21 & 37.5 & 1 & 7.14 \\
\hline & $31-50$ years & 0 & 0 & 0 & 0 & 0 & 0 \\
\hline & $>50$ years & 0 & 0 & 0 & 0 & 0 & 0 \\
\hline \multirow{4}{*}{$\begin{array}{l}\text { Annual revenue (millions } \\
\text { francs } \mathrm{CFA} \text { ) }\end{array}$} & $<25$ & 25 & 35.71 & 11 & 19.64 & 14 & 100 \\
\hline & $25-99$ & 29 & 41.43 & 29 & 51.79 & 0 & 0 \\
\hline & $100-249$ & 16 & 22.86 & 16 & 28.57 & 0 & 0 \\
\hline & 250 and above & 0 & 0 & 0 & 0 & 0 & 0 \\
\hline \multirow[t]{9}{*}{ Industry } & Bank and Insurance & 21 & 30 & 7 & 12.5 & 14 & 100 \\
\hline & IT & 22 & 31.43 & 22 & 39.29 & 0 & 0 \\
\hline & Health services & 6 & 8.56 & 6 & 10.71 & 0 & 0 \\
\hline & Telecommunication & 14 & 20 & 14 & 25 & 0 & 0 \\
\hline & Construction & 1 & 1.43 & 1 & 1.79 & 0 & 0 \\
\hline & $F \& B$ & 2 & 2.86 & 2 & 3.57 & 0 & 0 \\
\hline & Wholesale & 0 & 0 & 0 & 0 & 0 & 0 \\
\hline & Textile & 2 & 2.86 & 2 & 3.57 & 0 & 0 \\
\hline & Others & 2 & 2.86 & 2 & 3.57 & 0 & 0 \\
\hline \multicolumn{8}{|l|}{ Non Management Staff } \\
\hline \multirow[t]{2}{*}{ Gender } & Male & 41 & 54.67 & 37 & 56.01 & 4 & 44.44 \\
\hline & Female & 34 & 45.33 & 29 & 43.99 & 5 & 55.56 \\
\hline \multirow[t]{4}{*}{ Age } & $<30$ years & 14 & 18.67 & 13 & 19.7 & 1 & 11.11 \\
\hline & $31-40$ years & 38 & 50.67 & 32 & 48.5 & 6 & 66.67 \\
\hline & $41-50$ years & 20 & 26.66 & 18 & 27.26 & 2 & 22.22 \\
\hline & $>50$ years & 3 & 4 & 3 & 4.54 & 0 & 0 \\
\hline \multirow[t]{3}{*}{ Longivity of Service } & $<5$ years & 23 & 30.67 & 21 & 31.82 & 2 & 22.22 \\
\hline & $5-10$ years & 27 & 36 & 24 & 36.36 & 3 & 33.34 \\
\hline & $11-30$ years & 25 & 33.33 & 21 & 31.82 & 4 & 44.44 \\
\hline \multirow[t]{3}{*}{ Industry } & Bank and Insurance & 26 & 36.67 & 17 & 26 & 9 & 100 \\
\hline & $\mathrm{F} \& \mathrm{~B}$ & 22 & 29 & 22 & 34 & 0 & 0 \\
\hline & Health services & 6 & 8 & 6 & 10 & 0 & 0 \\
\hline
\end{tabular}




$\begin{array}{lllllll}\text { Telecommunication } & 13 & 17 & 13 & 19.69 & 0 & 0 \\ \text { Construction } & 1 & 1.33 & 1 & 1.52 & 0 & 0 \\ \text { IT } & 2 & 2.67 & 2 & 3.03 & 0 & 0 \\ \text { Wholesale } & 0 & 0 & 0 & 0 & 0 & 0 \\ \text { Textile } & 1 & 1.33 & 1 & 1.52 & 0 & 0 \\ \text { Others } & 3 & 4 & 3 & 4.24 & 0 & 0\end{array}$

\begin{abstract}
5. DATA ANALYSIS AND RESULTS
Analvtic Method

Partial least square structural equation modelling (PLS-SEM) technique is the data analytic procedure used in this study. The main choice for PLS-SEM which is the variance-based partial least square structural equation modelling is because contrary to the covariance-based, PLS-SEM is not stringent on the use of large sample sizes (Hair et al., 2017). Hence, given the sample size, PLS-SEM is more appropriate for its analysis. Also, it has no restrictions related to model complexity and has been recommended as an alternative technique if there exist predictive hypotheses (Hair et al., 2017; Rigdon et al., 2017) since it mainly centres on the interaction between predictions and the testing of theories (Shmueli, 2010) as is the case of the present research. Following, Anderson and Gerbing (1988), the analysis utilizes the two-step approach which firstly involves an assessment of the measurement model's psychometric properties followed by the hypothesized structural model. Prior importation of the data set in to SmartPLS version 3.0 which has been popularly applied in numerous social science-related disciplines (Haire et al., 2018) for the analysis proper, some preliminary data evaluation processes (unengaged response and missing data analysis) was firstly carried out in excel and SPSS.
\end{abstract}

\title{
5.1. Reliability and Validity
}

Table 2: Measurement Model

\begin{tabular}{|c|c|c|c|c|c|}
\hline \multicolumn{6}{|l|}{ Table: Measurement Model } \\
\hline $\begin{array}{l}\text { Constructs, Dimensions and Indicators } \\
\text { Mimetic Pressure (MP) }\end{array}$ & $\lambda$ & Mean & S.D & Skewness & Kurtosis \\
\hline $\begin{array}{l}\text { Our competitors who have adopted big data and predictive analytics have } \\
\text { greatly benefitted. }\end{array}$ & $0.843 * * *$ & 3.357 & 0.926 & -0.892 & 0.520 \\
\hline $\begin{array}{l}\text { Our competitors who have adopted big data and predictive analytics are } \\
\text { favourably perceived by the others in the same }\end{array}$ & $0.938 * * *$ & 3.371 & 0.959 & -0.220 & -0.242 \\
\hline $\begin{array}{l}\text { Our competitors who have adopted big data and predictive analytics are } \\
\text { favourably perceived by their suppliers and customers. } \\
\text { Human Skills (HS) }\end{array}$ & $0.838 * * *$ & 3.514 & 1.025 & -0.528 & -0.245 \\
\hline $\begin{array}{l}\text { We recruit new employees who have good exposure to big data and predictive } \\
\text { analytics. }\end{array}$ & $0.825 * * *$ & 3.557 & 0.905 & -0.648 & -0.043 \\
\hline Our big data analytics staff has the right skills to do the job successfully. & $0.898 * * *$ & 3.829 & 1.082 & -0.755 & -0.169 \\
\hline Our big data staff has right education & $0.894 * * *$ & 3.686 & 0.964 & -0.594 & -0.169 \\
\hline $\begin{array}{l}\text { Our big data staff holds suitable years of experience in big data environment. } \\
\text { Big Data and Predictive Analytics (BDPA) }\end{array}$ & $0.846^{* * *}$ & 3.571 & 0.935 & -0.534 & -0.215 \\
\hline Data capturing system & $0.744 * * *$ & 3.843 & 0.995 & -1.099 & 1.228 \\
\hline Document management system & $0.731 * * *$ & 4.029 & 0.810 & -1.042 & 2.075 \\
\hline Investment intelligence system & $0.681 * * *$ & 3.343 & 1.120 & -0.531 & -0.368 \\
\hline Visualization & $0.796 * * *$ & 3.786 & 1.027 & -1.091 & 1.167 \\
\hline Data mining & $0.677 * * *$ & 3.371 & 0.965 & -0.597 & 0.499 \\
\hline \multicolumn{6}{|l|}{ Transformational Leadership (TL) } \\
\hline $\begin{array}{l}\text { Employees are inspired with the leadership's plans and are committed to the } \\
\text { vision and dream of the leadership for the future. }\end{array}$ & $0.925 * * *$ & 3.586 & 1.325 & -0.697 & -0.676 \\
\hline $\begin{array}{l}\text { Employees are encouraged to work together as a team thereby fostering } \\
\text { collaboration amongst work groups for the same goals }\end{array}$ & $0.644 * * *$ & 4.443 & 0.804 & -1.663 & 2.592 \\
\hline $\begin{array}{l}\text { Management and other institutional leaders are knowledgeable and well } \\
\text { informed and have a clear understanding of the institution's vision } \\
\text { Operational Performance (OP) }\end{array}$ & $0.561 * * *$ & 3.657 & 1.081 & -0.421 & -0.660 \\
\hline Our firm is successful in gaining economies of scale & $0.837 * * *$ & 4.143 & 0.816 & -0.435 & -0.931 \\
\hline The productivity of labor has been improved & $0.750 * * *$ & 3.771 & 0.814 & -0.038 & -0.681 \\
\hline Our customers' requests have been adequately responded to & $0.782 * * *$ & 3.800 & 0.838 & -1.088 & 2.243 \\
\hline Our meetings and discussions have been held efficiently and effectively & $0.698 * * *$ & 3.771 & 0.796 & -0.775 & 1.361 \\
\hline
\end{tabular}

The reliability of various items to their respective constructs was examined by assessing the items outer loadings (Hair et al., 2019). A significant number of indicators recorded outer loading $>0.7 .08$ (Hair et al., 2019) while only 5 indicators recorded loading $<0.708$ but between 0.560 and 0.681 (Table 2). This indicates that the model has sufficient items reliability. To assess and ascertain the internal consistency and scale reliability, the reliability coefficient Cronbach's 
alpha was conducted for each construct, MP, HS, TL, BDPA and OP and they were $0.851,0.891,0.663,0.777$ and 0.767 respectively (Table 3 ). With the exception of TL with 0.663 , all the other latent variables are $>0.7$. However, this value is close to the threshold value of 0.7 and the construct is sufficiently within the threshold for all the other criteria $(C R$, rho_A, AVE, HTMT) as shown in table 3.

The scale composite reliability (SCR) factor which analyzes the internal consistency of a set of measures (Aydiner et al., 2019) specifies that a threshold SCR value of at least 0.70 for a construct signifies sufficient reliability (Fornell and Larcker, 1981). The SCR values are within this threshold. Therefore, all constructs use within the present research are sufficiently reliable (table 3 ). The constructs convergent validity was confirmed and ascertained by the average variance extracted (AVE) and rho_A estimates for all constructs. Table 3 shows that AVE and the rho_A values are all $>0.5$ and $>0.7$ respectively. This signifies that the constructs highly converge to explain the variance of all items (Hair et al., 2019). Furthermore, the distinctness of each construct from another was measured by discriminant validity using the heterotraitmonotrait (HTMT) ratio (Henseler et al., 2015). The maximum HTMT value is 0.818 and this is $<0.850$ which is the most conservative critical HTMT value (Henseler et al., 2015) (Table 3). Therefore discriminant validity is established in the proposed model.

Table 3: Reliability and Validity

\begin{tabular}{llllllllll}
\hline \multicolumn{10}{l}{ Table: Inter-construct correlations, Convergent and discriminant validity } \\
\hline Constructs & $\boldsymbol{C A}$ & $\boldsymbol{r h o}$ & $\boldsymbol{S C R}$ & $\boldsymbol{A V E}$ & $\boldsymbol{B D P A}$ & $\boldsymbol{H S}$ & $\boldsymbol{M P}$ & $\boldsymbol{O P}$ & $\boldsymbol{T L}$ \\
$\boldsymbol{B D P A}$ & 0.777 & 0.782 & 0.848 & 0.529 & ${ }^{\boldsymbol{a}} \mathbf{0 . 7 2 7}$ & ${ }^{b} 0.325$ & 0.071 & 0.144 & 0.549 \\
$\boldsymbol{H S}$ & 0.891 & 0.918 & 0.923 & 0.750 & 0.498 & $\mathbf{0 . 8 6 6}$ & 0.242 & 0.410 & 0.380 \\
$\boldsymbol{M P}$ & 0.851 & 0.973 & 0.906 & 0.764 & 0.323 & 0.102 & $\mathbf{0 . 8 7 4}$ & 0.362 & 0.818 \\
$\boldsymbol{O P}$ & 0.767 & 0.767 & 0.852 & 0.591 & 0.632 & 0.359 & 0.173 & $\mathbf{0 . 7 6 9}$ & 0.313 \\
$\boldsymbol{T L}$ & 0.663 & 0.924 & 0.762 & 0.528 & 0.286 & 0.338 & 0.176 & 0.220 & $\mathbf{0 . 7 2 7}$ \\
\hline
\end{tabular}

Notes: $\boldsymbol{C A}=$ Cronbach's Alpha, $\boldsymbol{C R}=$ Composite Reliability, $\boldsymbol{r h o}=$ rho_A reliability indices, $\boldsymbol{A} \boldsymbol{V E}=$ Average Variance Extracted, $\boldsymbol{a}=$ Diagonal values in bold are the square root of AVE, $\boldsymbol{b}=$ Italicized values above the square root of AVE are Heterotrait-Monotrait (HTMT) ratios

\subsection{Structural Model Assessment}

Podsakoff et al., (2003) argue that in organizational and management research, there is a high probability of common method biases (CMB) when data is self-reported. This could be as a result of several reasons such as consistency motif, social desirability and leniency biases. The intensity of Common method bias (CMB) in the present research was examined by carrying out collinearity diagnostics (VIF) (Becker et al., 2015). The inner factor level VIF values that resulted from a complete collinearity test - for each construct use within the context of the present study were all $<3.3$ (Kock, 2015) (Table 4). Therefore, the model has no collinearity issues and the presence CMB is very minimal.

The R2 values of the endogenous constructs HS, BDPA and OP of $0.010,0.329$ and 0.495 respectively are within the threshold range between 0 and 1 whereas a higher value indicates a better explanatory power (fig 1). The effect sizes of MP on HS (0.011), HS on BDPA (0.257), MP on BDPA (0.099), TL on BDPA (0.010), TL on OP (0.001) and BDPA on OP (0.432).Cohen (1988) mentions that values above $0.02,0.15$ and 0.35 signify small, medium and large effect sizes respectively (table 6). The model's predictive capacity was examined by assessing Stone-Geisser's Q2. Q2 values $>0$ signify that Predictive accuracy is established (Shmueli et al., 2016).

Table 4: Common Method Bias (CMB)

\begin{tabular}{|l|l|l|l|l|l|}
\hline & $\begin{array}{l}\text { Big Data And } \\
\text { Predictive Analytics } \\
\text { (BDPA) }\end{array}$ & $\begin{array}{l}\text { Human } \\
\text { Skills } \\
\text { (HS) }\end{array}$ & $\begin{array}{l}\text { Mimetic } \\
\text { pressures } \\
\text { (IP) }\end{array}$ & $\begin{array}{l}\text { Operational } \\
\text { performance } \\
\text { (OP) }\end{array}$ & $\begin{array}{l}\text { Transformational } \\
\text { Leadership (TL) }\end{array}$ \\
\hline $\begin{array}{l}\text { Big Data And Predictive } \\
\text { Analytics (BDPA) }\end{array}$ & 1.753 & 1.733 & 1.395 & 1.710 \\
\hline Human Skills (HS) & 1.252 & & 1.380 & 1.361 & 1.298 \\
\hline Mimetic pressures (MP) & 1.050 & 1.128 & & 1.126 & 1.107 \\
\hline Operational performance (OP) & 1.184 & 1.582 & 1.623 & & 1.395 \\
\hline $\begin{array}{l}\text { Transformational Leadership } \\
\text { (TL) }\end{array}$ & 1.168 & 1.091 & 1.169 & 1.151 & \\
\hline
\end{tabular}




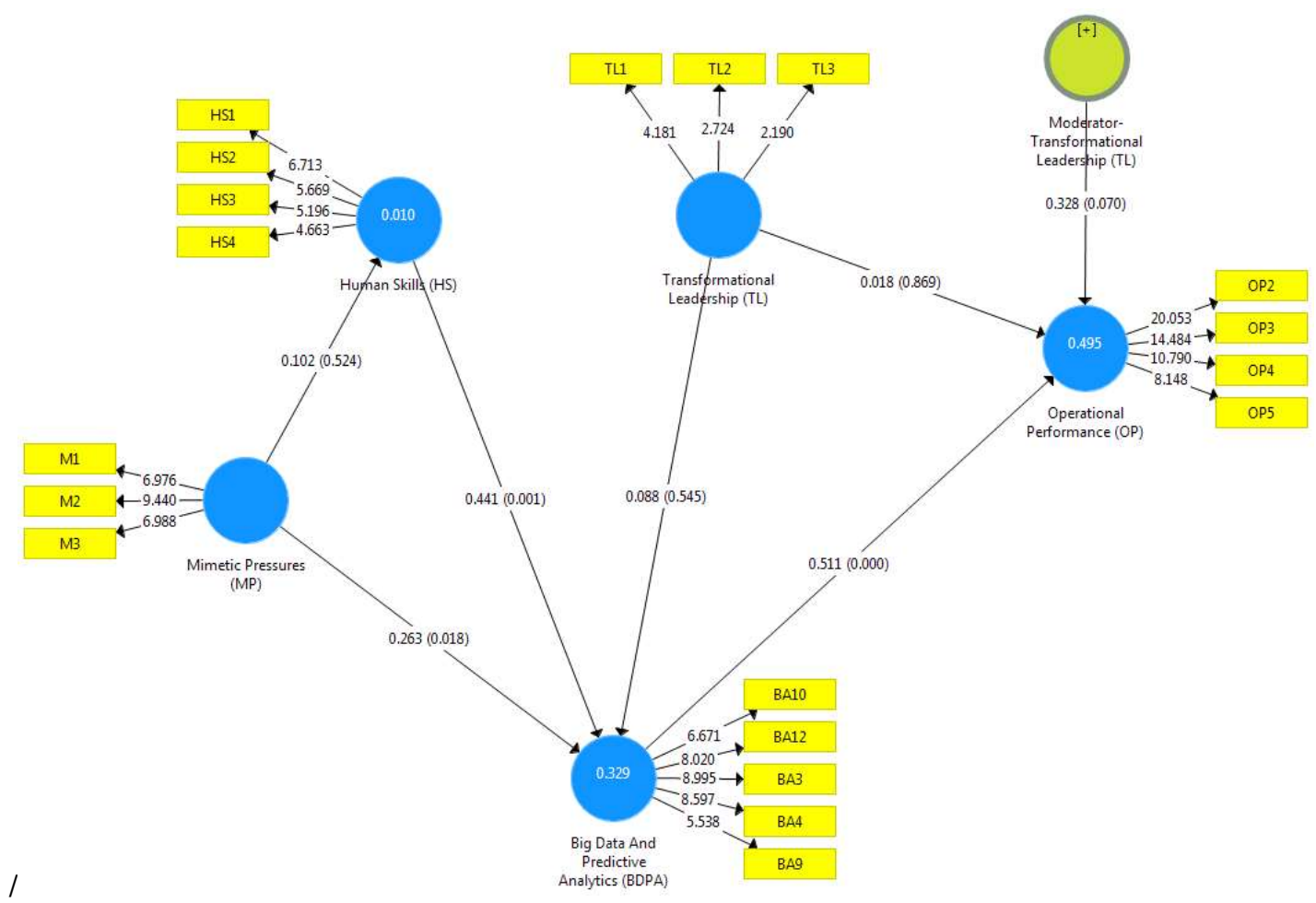

Fig 2: Final PLS Model.

The total Stone-Geisser's Q2 values for the endogenous constructs HS, BDPA and OP are $\quad-0.012,0.142$ and 0.235. Therefore with the exceptions of HS, predictive accuracy is established for the endogenous constructs BDPA and OP in the proposed model (table 5).

Table 5: Construct Crossvalidated Redundancy

\begin{tabular}{|l|l|l|l|}
\hline & $S S O$ & $S S E$ & $Q^{2}(=1-S S E / S S O)$ \\
\hline $\begin{array}{l}\text { Big Data and Predictive } \\
\text { Analytics (BDPA) }\end{array}$ & 490 & 412.743 & 0.142 \\
\hline Human Skills (HS) performance & 280 & 391.564 & -0.012 \\
\hline $\begin{array}{l}\text { Operational } \\
\text { (OP) }\end{array}$ & 210.768 & 0.235 \\
\hline
\end{tabular}

Notes: Stone-Geisser's Q2 examined 8 cases

\section{Hypothesis testing}

The PLS path coefficients are interpreted as standardized beta coefficient and corresponding results are: H1 (MP $\rightarrow$ HS) $(\beta=0.102, p=0.524), \mathrm{H} 2(\mathrm{HS} \rightarrow \mathrm{BDPA})(\beta=0.441, p=0.001), \mathrm{H} 3(\mathrm{MP} \rightarrow \mathrm{BDPA})(\beta=0.263, p=0.018), \mathrm{H} 4$ $(\mathrm{BDPA} \rightarrow \mathrm{OP})(\beta=0.511, p=<0.001), \mathrm{H} 5(\mathrm{TL} \rightarrow \mathrm{BDPA})(\beta=0.088, p=0.545), \mathrm{H} 6(\mathrm{TL} \rightarrow \mathrm{OP})(\beta=0.018, p=0.869)$. The moderating effect of TL was tested by joining the paths BA and OP (BDPA*TL $\rightarrow$ OP) (i.e. H7) $(\beta=0.328, p=$ 0.070). Control variable (IND $\rightarrow \mathrm{OP})(\beta=-0.332, p=0.279)$. These results are reported in table 6 .

Table 6: Results of Path Analysis

\begin{tabular}{|c|c|c|c|c|}
\hline \multicolumn{5}{|l|}{ Results of the Path Analysis } \\
\hline Hypothesis & $\begin{array}{l}\beta \\
\text { values }\end{array}$ & $\begin{array}{l}t \\
\text { statistics }\end{array}$ & $\begin{array}{l}\text { palues } \\
\text { valu }\end{array}$ & $f^{2}$ \\
\hline $\begin{array}{l}\text { H1: Mimetic Pressures (MP) has a significant positive impact on } \\
\text { the building and selection of Human Skills }\end{array}$ & 0.102 & 0.621 & 0.524 & 0.011 \\
\hline $\begin{array}{l}\text { H2: Human Skills has a significant positive impact on the adoption } \\
\text { of BDPA }\end{array}$ & 0.441 & 3.403 & 0.001 & 0.257 \\
\hline $\begin{array}{l}\text { H3: Mimetic Pressures has a significant positive impact on the } \\
\text { adoption of BDPA. }\end{array}$ & 0.263 & 2.298 & 0.018 & 0.099 \\
\hline $\begin{array}{l}\text { H4: BDPA has a significant positive impact on the firm's } \\
\text { operational performance. }\end{array}$ & 0.511 & 4.353 & $<0.001$ & 0.010 \\
\hline H5: Transformational leadership has a significant positive impact & 0.088 & 0.596 & 0.545 & 0.001 \\
\hline
\end{tabular}




\begin{tabular}{|l|l|l|l|l|}
\hline on the adoption of BDPA. & & & & \\
\hline $\begin{array}{l}\text { H6: Transformational leadership has a significant positive impact } \\
\text { on the firm's operational performance. }\end{array}$ & 0.018 & 0.164 & 0.869 & 0.432 \\
\hline $\begin{array}{l}\text { H7: Transformational leadership will further strengthen the impact } \\
\text { of adopting Business Analytics on the firm's operational } \\
\text { performance }\end{array}$ & 0.328 & 1.742 & 0.070 & - \\
\hline
\end{tabular}

Notes:= The PLS path coefficients are interpreted as standardized beta coefficient. Standardized bootstrapping upon 1000 runs.

Also, following Shmueli et al., (2016), the ability of the model's predicting constructs to predict the results of an out of sample study was examined by assessing Q2 pls predict values for all the endogeneous constructs. A positive Q2 pls predict value signifies that predictive validity is established for all endogenous latent construct in the PLS-SEM model (Shmueli et al., 2016). With the exception of HS (-0.029), predictive validity is established for all the other 2 endogenous latent constructs BDPA (0.080) and OP (0.074) (table 7).

Table 7: LV Prediction Summary

Notes: Predictive validity examined upon 7 sub-samples

\begin{tabular}{|l|l|}
\hline & $Q^{2}$ predict \\
\hline Big Data and Predictive Analytics (BDPA) & $\underline{0.080}$ \\
\hline Human Skills (HS) & $\underline{-0.029}$ \\
\hline$\underline{\text { Operational performance (OP) }}$ & $\underline{0.074}$ \\
\hline
\end{tabular}

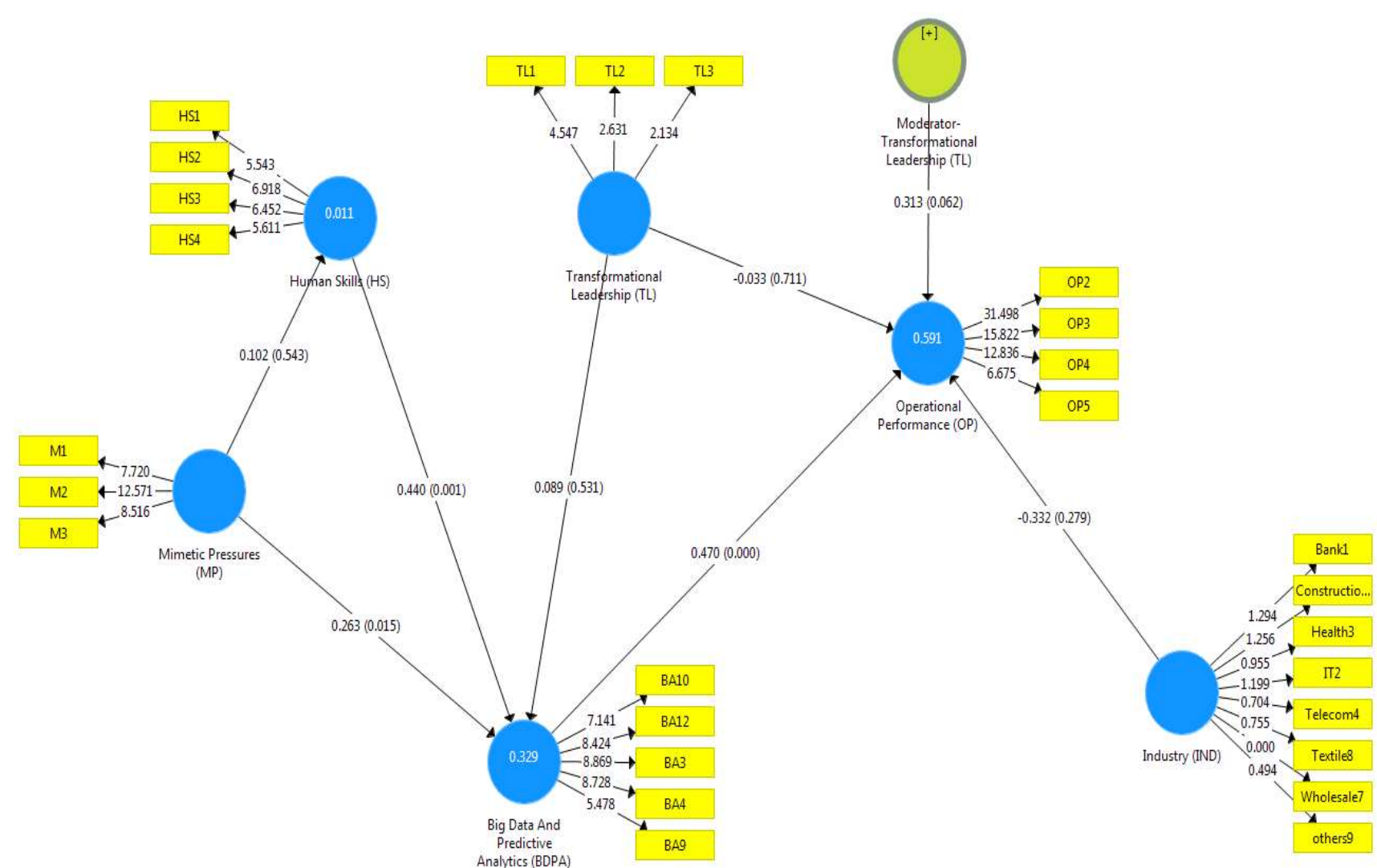

Fig 3: Final PLS Model including Statistical Control

\section{DISCUSSION}

The present study sought to analyze the impact of MP and the firm's HS in the adoption of BDPA. Also, the impact of TL in the adoption of BDPA and OP as well as TL's moderation role in the BDPA - OP nexus is ascertained. Hypothesis 1 of the present study opined that MP has a significant positive impact on the building and selection of HS. From the empirical results, MP has a positive but insignificant impact on the building and selection of the firm's HS. Therefore $H 1$ is rejected. White et al., (2003) argues that flexible oriented firms would not succumb to all MP from the environment since it will prefer to initiate its own distinctive practices in order to differentiate itself from other firms and to gain 
competitive advantage through diversification. This could explain the insignificance noticed in the results. Previous findings have highlighted that Institutional pressures which comprise coercive, normative and mimetic pressures directly affect the deployment of HS (Bag et al., 2020; Dubey et al., 2019, Cruz-Jesus et al., 2018, Gupta \& George, 2016). This result could further be explained by the fact that in building and selecting HS, firms in Cameroon are mush more influence by the other forms of pressures. This, therefore, serves as a basis for further investigation. Hypothesis 2 states that HS has a significant positive impact in the adoption of BDPA. The results of the analysis are in line with this hypothesis, therefore H2 is supported. Dubey et al., (2019) argue that the deployment of HS intends influences the adoption of BDPA. According to Kornacka (1997), the most valuable resource that a firm has are its employees. The accumulation of human capital results from the fact that each of these employees has the ability to learn and develop their potentials and in recent times, IT innovations do not only require organizational capital to succeed but equally human capital (Kornacka, 1997). Theories such as the RBT have been singly used by previous researchers (Aydiner et al., 2019; Chae et al., 2014; Chae, Olson \& Sheu, 2014; Cosic, Shanks \& Maynard, 2015) to justify the adoption of BA. However, the RBT by itself is not without limitations. Oliver (1997) argues that the RBT focuses less on the context and processes that lead to the selection of resources whereas other factors such as societal influences are equally influential in the deployment of resources. Integratively, the Institutional theory and the RBT have been extensively studied and linked to among others sustainable competitive advantage, management practises, corporate social responsibility, organizational knowing and dynamic capabilities (Oliver, 1997; Yang \& Konrad, 2011; Nair \& Bhattacharyya, 2019; Takahashi \& Sander, 2017). However, an understanding of the combined effects of both theories in justifying the adoption of BDPA hasn't still been adequately researched. Hence, this study complements previous studies (Bag et al., 2020; Dubey et al., 2019; Cruz-Jesus et al., 2018, Gupta \& George, 2016) and further enrich existing research by examining the combined effects of MP and HS on firms in Cameroon in the adoption of BDPA. Conclusively and as empirically proven, in Cameroon MP positively influences the deployment of firms' HS which intends has positive significant effects in the adoption of BDPA. Hypothesis 3 postulates that MP has a significant positive impact in the adoption of BDPA. Empirical result is in support of the stated hypothesis (H3 supported) and this signifies that institutional pressures are strategic antecedents for the adoption of BDPA. Contrary to the past, advances in IT is less becoming a major factor taken in to account in building BDPA capabilities. Instead, external pressures have become the bases upon which organizations rely before making decision with regards to the adoption of BDPA (Dubey et al., 2019). The existence of the direct connection between BDPA and OP was equally tested- hypothesis 4 . Empirical results proved that there exists a significant positive impact of BDPA on the firm's OP (H4 supported). According to Ramanathan et al., (2017), in real organizational settings, the repacautions of business analytics, first of all, translates in to process-level performances such that competitive advantage is created for the firm. Analytics encryptions are joined together with business processes and as a result of this integration, insights gained from the former is conveyed to the later and this increases the efficiency of business processes (Tan et al., 2016; Chen et al., 2015). Hence, Big data technologies have the ability of improving the firm's operational performance through its business processes (Holsapple et al., 2014; Bolsinger et al., 2015; Van Looy \& Shafagatova, 2016). H5 postulates that TL has a significant positive impact on the adoption of BDPA. Empirical results reject this hypothesis (H5 not supported). The findings outcome proved that TL has a positive but insignificant effect in the adoption of BDPA. This may be due to the fact that there isn't a clear understanding of the role of leaders in the adoption of BDPA. As suggested by Bass and Avolio (1993), TL often builds and articulate the desired organizational culture to followers as a means of facilitating the achievement of the organization's strategic vision. Omar et al., (2019) postulate that cultural evolutions need to surpass intuition and encourage the alignment of the firm's strategic vision and decisions to big data. Likewise, the result provided is not in support of hypothesis 6 (H6 not supported) which postulates that TL has a significant positive impact on the firm's OP. Also, TL was found to have a positive but insignificant impact on OP. In their attempt to build and improve organizational processes, performance is the most important factor that leaders consider (Kroll, 2016). Transformational leaders should be able to steer up changes in individual behaviour and commitment which creates the supports that is needed for desired operational outcomes (Trmal et al., 2015). Likewise, De Jong and Bruch (2013) postulates that transformational leaders have a direct effect on organizational climate which creates an environment whereby employees are motivated and energized to work together in order to achieve the organization's goals. Findings could be explained by the inability of the leaders to demonstrate essential TL attributes within the organization that will make employees become more committed and work together with the purpose of further boosting up OP. Hypothesis 7 states that TL will further strengthen the impact of BDPA on OP. The study's results indicate that the moderating role of TL in the BDPA- OP link is quasi - significant. This suggests that TL bearly strengthen the direction of the association between BDPA and OP. This finding is narrowly in support of the conceptual model suggesting that the influence of BDPA on OP of firms in Cameroon is neither very much aligned nor catalyzed through TL. Rubin and his co-authors opined that TL represents the most active form of leadership where leaders unanimously with followers work for the realization of organizational goals (Rubin, Munz, \& Bommer, 2005). In addition to the insufficiency in TL attributes, in the context of big data capabilities, managers are recommended to understand how and where knowledge exploited is applied and performance will be further enhanced only if manager can effectively anticipate the capabilities of the knowledge extracted from data (Gupta and George, 2016). Also, it is important to emphasize that BA consist of an ecosystem where all actors are recommended to work in unanimity to boost performance while delivering value to customers (Omar et al., 2019). 
Furthermore, from observations Industry is not significantly associated with OP. However, to obtain more insight, from the nine industry segments the three most respondent industries (Bank, F\&B and telecommunication) who responded to more than $80 \%$ of the questionnaires were selected for a multi-group analysis. The outcome of the multi-group analysis indicates that the effect of MP on HS was significant for the case of the telecommunication industry with the existence of a significant difference between the Banking and Telecommunication industry. Also, the effects of MP on BDPA and HS on BDPA was found to be significant in the F\&B industry while TL in the adoption of BDPA was significant in the Banking industry. Appendix $\mathrm{C}$ shows the PLS results.

\section{CONCLUSION}

This study set out as the first research examining the moderating role of TL in the linkage between BDPA and OP. Also, MP and HS are examined as antecedents for the adoption BDPA. As discussed, the study revealed that MP and HS are important progenitors for the adoption of BDPA. TL has a positive but insignificant influenced in the adoption of BDPA and OP. Also, TL has an apparent significant strength on the BDPA-OP link. This indicates the existence of a gap in the transformational aspects of institutional leaders as concerns analytics and its influence in the achievement of the firm's major strategic goals -operational performance in the present case. Thus, regardless of how effective TL attributes may be applied in different organizations, these are not so much related to how well value from adopting BDPA is been added to the firm. As recommended from these findings a clear understanding of MP, the firm's HS and TL in the adoption of BDPA may further enhance the impact of BDPA on OP. These findings prove that organizations in Cameroon are yet to still realize the full benefits of adopting BDPA.

\subsection{Theoretical Implications}

This study integrates the institutional theory and the resource-based theory (RBT) in explaining the process of adopting BDPA. Previous studies have as well integrated these two theoretical perspectives (Bag et al., 2020, Dubey et al., 2019), however, 2 important aspects of this study stand as contributions to the existing body of literature. This study is the first to examine the moderating role of TL between the BDPA and OP nexus. Leadership and aspects of leadership such as leadership behaviour and style have been studied extensively and linked to among others, performance, employee creativity, climate for organizational innovation and constructs such as culture and strategic planning (Bass \& Avolio, 1993; Schein, 2004; Xenikou \& Simosi, 2006; Sarros, Cooper, \& Santora, 2008; Zhang \& Bartol, 2010; Sully de Luque et al., 2008). This study sheds light on the fact that the TL style can be integrated together with other organizational constructs in order to explain the process of adopting BDPA.

\subsection{Managerial Implications}

The study findings indicate that transformational leaders are yet to be active actors in adopting BDPA as well as its impact on the OP of firms in Cameroon. This is a clear managerial gap that institutional leaders have to examine in order to establish their organizations in today's big data dynamic world. Therefore as useful guidance to management, TL attributes, as well as managerial skills within the firms, needs to be effectively addressed. Also, despite the extent to which BDPA must have been adopted in the firm, its related benefits will only be attainable if applied TL attributes relate to how well value obtained from BDPA adoption is been added to the firm.

\subsection{Limitation and future research}

This study focuses on the Institutional theory and the Resource Based Theory in order to explain the process of adopting BDPA. These theories are not without limitations. For example, as a limitation, the RBT has been criticized for its inability to identify the conditions under which resources are selected (Ling-Yee, 2007). In this regard, I recommend future research to replicate the model and embrace other theoretical views such as the dynamic capability theory, contingency theory and industry analysis in order to enhance the understanding of the process of adopting BDPA.

Another limitation was the inability to reach a relatively larger sample size. It is therefore recommended that future research should allocate a relatively long time for data collection, develop and test the study's hypothesis in another country. Also, comparative empirical studies amongst industries is encouraged as similarities and differences discovered can serve as a research benchmark.

This study examines the effects of MP in building and selecting HS meanwhile other forms of Institutional pressures exist such as coercive and normative pressures. Future research should also consider to investigate their effects in building and the selection of the firm's HS. Also, a comparative study between the three forms of institutional pressures is encouraged.

Lastly, the present study applied a cross-sectional research design. It is recommended that longitudinal studies be conducted as cross-sectional research may also limit causal inferences and bring about possibility of reverse causal relationships (Sarros, Cooper, \& Santora, 2008). Likewise, cross-sectional research as they are carried out at a point in time decrease the opportunity to examine the variables for longer periods. 
Big Data Predictive Analytics and Performance: The Role of Transformational Leadership

\begin{tabular}{|c|c|c|}
\hline & \multicolumn{2}{|l|}{ APPENDIX A: Measurement of Constructs } \\
\hline & CONSTRUCTS & SOURCES \\
\hline & INSTITUTIONAL PRESSURES (IP) & Gupta \&George, 2016; Dubey et al., 2019 \\
\hline & \multicolumn{2}{|c|}{$\begin{array}{l}\text { Please indicate the level of your agreement to the following statements that are related to the effects of the external pressure and the internal } \\
\text { resource development in order to achieve BA (Business Analytics) adoption in order to enhance your firm operational performance using } \\
5 \text {-point scales ( } 1 \text { = "strongly disagree" to } 5=\text { "strongly agree") and ( } 1 \text { = "very low" to } 5=\text { "very high") }\end{array}$} \\
\hline 1. & \multicolumn{2}{|c|}{ Our competitors who have adopted big data and predictive analytics have greatly benefitted. } \\
\hline 2. & \multicolumn{2}{|c|}{ Our competitors who have adopted big data and predictive analytics are favourably perceived by the others in the same } \\
\hline 3. & \multicolumn{2}{|c|}{ Our competitors who have adopted big data and predictive analytics are favourably perceived by their suppliers and customers. } \\
\hline & FIRM RESOURCES (FR) & Gupta and George (2016 \\
\hline 4. & \multicolumn{2}{|l|}{ We provide big data related training to our employees. } \\
\hline 5. & \multicolumn{2}{|c|}{ We recruit new employees who have good exposure to big data and predictive analytics. } \\
\hline 6. & \multicolumn{2}{|c|}{ Our big data analytics staff has the right skills to do the job successfully. } \\
\hline 7. & \multicolumn{2}{|c|}{ Our big data staff has right education } \\
\hline 8. & \multicolumn{2}{|c|}{ Our big data staff holds suitable years of experience in big data environment. } \\
\hline 9. & \multicolumn{2}{|c|}{ Our big data and predictive analytics managers have strong understanding of business. } \\
\hline 10. & \multicolumn{2}{|c|}{ Our big data and predictive analytics managers are able to coordinate effectively with all intra departments, suppliers and customers. } \\
\hline & $\begin{array}{l}\text { BIG DATA AND PREDICTIVE ANALYTICS } \\
\text { (BDPA) }\end{array}$ & $\begin{array}{l}\text { Zwass (1998), Alter (2002), Sharda et al. (2014), Laudon \& Laudon (2013) and Hindle } \\
\text { and Vidgen (2018) }\end{array}$ \\
\hline & \multicolumn{2}{|c|}{ Please identify the relative use of the following BA applications in your firm using 5-point scales (ranging from $1=$ "never" to $5=$ "always". } \\
\hline 11. & \multicolumn{2}{|l|}{ Information propagation } \\
\hline 12. & \multicolumn{2}{|l|}{ Data warehousing } \\
\hline 13. & \multicolumn{2}{|l|}{ Data capturing system } \\
\hline 14. & \multicolumn{2}{|l|}{ Document management system } \\
\hline 15. & \multicolumn{2}{|l|}{ Marketing intelligence system } \\
\hline 16. & \multicolumn{2}{|l|}{ Investment intelligence system } \\
\hline 17. & \multicolumn{2}{|l|}{ Data mining } \\
\hline 18. & \multicolumn{2}{|l|}{ Decision support system } \\
\hline 19. & \multicolumn{2}{|l|}{ Visualization } \\
\hline & OPERATIONAL PERFORMANCE (OP) & $\begin{array}{l}\text { Mahmood and Soon (1991); Elbashir et al. (2008), Bayraktar et al. (2009), Mclaren et } \\
\text { al. (2011), Mithas et al. (2011) and Luo et al. (2012). }\end{array}$ \\
\hline & \multicolumn{2}{|c|}{$\begin{array}{l}\text { Please indicate the level of your agreement to the following statements that are related to the effects of BA applications on your firm's } \\
\text { operational performance using } 5 \text { - point scales ( } 1=\text { "strongly disagree" to } 5=\text { "strongly agree"). }\end{array}$} \\
\hline 20. & \multicolumn{2}{|c|}{ Our firm has rapid and effective internal and external coordination for its regional, national and global activities } \\
\hline 21. & \multicolumn{2}{|c|}{ Our firm is successful in gaining economies of scale } \\
\hline 22. & \multicolumn{2}{|c|}{ The productivity of labor has been improved } \\
\hline 24. & \multicolumn{2}{|c|}{ Our customers' requests have been adequately responded to } \\
\hline 25. & \multicolumn{2}{|c|}{ Our meetings and discussions have been held efficiently and effectively } \\
\hline
\end{tabular}

\begin{tabular}{|l|l|l|}
\hline & APPENDIX B: Measurement of Constructs \\
\hline & CONSTRUCTS & SOURCES \\
\hline & TRANSFORMATIONAL LEADERSHIP (TL) & $\begin{array}{l}\text { Zhang \& Bartol, 2010; Luque, Washburn, Waldman, \& House, 2008 and Rubin, Munz, } \\
\text { \& Bommer, 2005 }\end{array}$ \\
\hline & $\begin{array}{l}\text { Please indicate the level of your agreement to the following statements that are related Transformational Leadership perceptions in your } \\
\text { organization using 5- point scales (1 = "strongly disagree" to 5 = "strongly agree"). }\end{array}$ \\
\hline 1. & Employees are inspired with the leadership's plans and are committed to the vision and dream of the leadership for the future. \\
\hline 2. & Employees are encouraged to work together as a team thereby fostering collaboration amongst work groups for the same goals \\
\hline 3. & Management and other institutional leaders are knowledgeable and well informed and have a clear understanding of the institution's vision \\
\hline 4. & Management shows confidence in employees' capacity to perform at high levels \\
\hline 5. & Employees are often consulted on all decision making \\
\hline
\end{tabular}




\begin{tabular}{|c|c|c|c|c|c|c|}
\hline \multirow[t]{2}{*}{ APPENDIX: C } & ath Ana & sis- Mul & Froup An: & ysis & & \\
\hline & $\begin{array}{c}\beta \\
\text { values } \\
\text { Bank }\end{array}$ & $\begin{array}{c}\beta \\
\text { values } \\
F \& B\end{array}$ & $\begin{array}{c}\beta \\
\text { values } \\
\text { Telecom }\end{array}$ & $\begin{array}{c}p \\
\text { values } \\
\text { Bank }\end{array}$ & $\begin{array}{c}p \\
\text { values } \\
F \& B\end{array}$ & $\begin{array}{c}p \\
\text { values } \\
\text { Telecom }\end{array}$ \\
\hline Mimetic Pressures $(\mathrm{MP}) \rightarrow$ Human Skills & 0.496 & 0.218 & -0.726 & 0.083 & 0.369 & $<0.001$ \\
\hline Analytics (BDPA) & 0.250 & 0.507 & 0.155 & 0.423 & 0.003 & 0.795 \\
\hline $\begin{array}{l}\text { Mimetic Pressures }(\mathrm{MP}) \rightarrow \text { Big Data Predictive } \\
\text { Analytics (BDPA) }\end{array}$ & 0.210 & 0.379 & 0.183 & 0.403 & 0.031 & 0.690 \\
\hline $\begin{array}{l}\text { - Big Data and Predictive Analytics (BDPA) } \rightarrow \\
\text { Operational Performance (OP). }\end{array}$ & 0.817 & 0.723 & 0.882 & 0.007 & $<0.001$ & 0.075 \\
\hline $\begin{array}{l}\text { - Transformational Leadership (TL) } \rightarrow \text { The } \\
\text { Adoption of Big Data and Predictive Analytics } \\
\text { (BDPA) }\end{array}$ & 0.526 & -0.197 & 0.572 & 0.051 & 0.525 & 0.165 \\
\hline $\begin{array}{ll}\text { - } & \text { Transformational Leadership (TL) } \rightarrow \\
& \text { Operational Performance (OP) }\end{array}$ & 0.183 & -0.089 & -0.097 & 0.517 & 0.702 & 0.855 \\
\hline
\end{tabular}

\section{REFERENCES}

1. Aguilar-Saven, R. S. (2004). Business process modelling: Review and framework. International Journal of production economics, 90(2), 129-149.

2. Aktaş, E., Çiçek, I., \& Kıyak, M. (2011). The effect of organizational culture on organizational efficiency: The moderating role of organizational environment and CEO values. Procedia-Social and Behavioral Sciences, 24, 1560-1573.

3. Alqatawenh, A. S. (2018). Transformational leadership style and its relationship with change management. Verslas: teorija ir praktika, 19(1), 17-24.

4. Alter, S. (2002). The work system method for understanding information systems and information systems research. Communications of the Association for Information Systems, 9(1), 6.

5. Amit, R., \& Schoemaker, P. J. (1993). Strategic assets and organizational rent. Strategic management journal, 14(1), 33-46.

6. Anderson, J. C., \& Gerbing, D. W. (1988). Structural equation modeling in practice: A review and recommended two-step approach. Psychological bulletin, 103(3), 411.

7. Appelbaum, D., Kogan, A., Vasarhelyi, M., \& Yan, Z. (2017). Impact of business analytics and enterprise systems on managerial accounting. International Journal of Accounting Information Systems, 25, 29-44.

8. Apté, C., Dietrich, B., \& Fleming, M. (2012). Business leadership through analytics. IBM Journal of Research and Development, 56(6), 7-1.

9. Arif, S., \& Akram, A. (2018). Transformational leadership and organizational performance: the mediating role of organizational innovation. SEISENSE Journal of Management, 1(3), 59-75.

10. Bag, S., Pretorius, J. H. C., Gupta, S., \& Dwivedi, Y. K. (2020). Role of institutional pressures and resources in the adoption of big data analytics powered artificial intelligence, sustainable manufacturing practices and circular economy capabilities. Technological Forecasting and Social Change, 120420.

11. Baharuden, A. F., Isaac, O., \& Ameen, A. (2019). Factors Influencing Big Data \& Analytics (BD\&A) Learning Intentions with Transformational Leadership as Moderator Variable: Malaysian SME Perspective. International Journal Of Management And Human Science, 3(1), 10-20.

12. Barbuto, J. E., \& Burbach, M. E. (2006). The emotional intelligence of transformational leaders: A field study of elected officials. The Journal of social psychology, 146(1), 51-64.

13. Barney, J. 1991. Firm resources and sustained competitive advantage. Joumal of Management, 17(1): 99-119.

14. Barr-Pulliam, D., Brazel, J. F., McCallen, J., \& Walker, K. (2020). Data Analytics and Skeptical Actions: The Countervailing Effects of False Positives and Consistent Rewards for Skepticism. Available at SSRN 3537180.

15. Barr-Pulliam, D., Brown-Liburd, H. L., \& Sanderson, K. A. (2020). The effects of the internal control opinion and use of audit data analytics on perceptions of audit quality, assurance, and auditor negligence. Assurance, and Auditor Negligence (February 7, 2020).

16. Bass, B. M. (1985). Leadership and performance beyond expectations. Collier Macmillan.

17. Bass, B. M., \& Avolio, B. J. (1993). TRANSFORMATIONAL LEADERSHIP AND ORGANIZATIONAL CULTURE. Public Administration Quarterly, 17(1), 112-121.

18. Bass, B. M., \& Avolio, B. J. (1994). Transformational leadership and organizational culture. The International Journal of Public Administration, 17(3-4), 541-554.

19. Bayrak, T. (2015). A review of business analytics: A business enabler or another passing fad. Procedia-Social and Behavioral Sciences, 195, 230-239. 
20. Bayraktar, E., Demirbag, M., Koh, S. L., Tatoglu, E., \& Zaim, H. (2009). A causal analysis of the impact of information systems and supply chain management practices on operational performance: evidence from manufacturing SMEs in Turkey. International Journal of Production Economics, 122(1), 133-149.

21. Becker, J.-M., Ringle, C.M., Sarstedt, M. and Völckner, F. (2015), "How collinearity affects mixture regression results", Marketing Letters, Vol. 26 No. 4, pp. 643-659.

22. Berthod, O. (2011). On institutions, paths, and routes set in stone: The construction of a bridge as a case of path instantiation (Doctoral dissertation).

23. Bisogno, S., Calabrese, A., Gastaldi, M., \& Ghiron, N. L. (2016). Combining modelling and simulation approaches. Business Process Management Journal.

24. Björkman, I., Fey, C. F., \& Park, H. J. (2007). Institutional theory and MNC subsidiary HRM practices: evidence from a three-country study. Journal of International Business Studies, 38(3), 430-446.

25. Bolsinger, M. (2015). Bringing value-based business process management to the operational process level. Information systems and e-business management, 13(2), 355-398.

26. Boyd, D., \& Crawford, K. (2012). Critical questions for big data: Provocations for a cultural, technological, and scholarly phenomenon. Information, communication \& society, 15(5), 662-679.

27. Burns, J. M. (2004). Transforming leadership: A new pursuit of happiness (Vol. 213). Grove Press.

28. Carr, N. G. (2003). IT doesn't matter. Educause Review, 38, 24-38.

29. Chae, B., Olson, D., \& Sheu, C. (2014). The impact of supply chain analytics on operational performance: a resource-based view. International Journal of Production Research, 52(16), 4695-4710.

30. Chae, H. C., Koh, C. E., \& Prybutok, V. R. (2014). Information technology capability and firm performance: contradictory findings and their possible causes. Mis Quarterly, 38(1), 305-326.

31. Chen, I. J. and A. Paulraj (2004). 'Towards a theory of supply chain management: the constructs and measurements', Journal of Operations Management, 22, pp. 119-150.

32. Chen, Y., Wang, Y., Nevo, S., Benitez-Amado, J., \& Kou, G. (2015). IT capabilities and product innovation performance: The roles of corporate entrepreneurship and competitive intensity. Information \& Management, 52(6), 643-657.

33. Cohen, J. (1988), Statistical Power Analysis for the Behavioral Sciences: Lawrence Erlbaum Associates.

34. Colbert, A. E., Kristof-Brown, A. L., Bradley, B. H., \& Barrick, M. R. (2008). CEO transformational leadership: The role of goal importance congruence in top management teams. Academy of management journal, 51(1), 8196.

35. Columbus, L. (2014). Roundup of analytics, big data \& business intelligence forecasts and market estimates, 2014. Forbes.

36. Cosic, R., Shanks, G., \& Maynard, S. B. (2015). A business analytics capability framework. Australasian Journal of Information Systems, 19.

37. Cosic, R., Shanks, G., \& Maynard, S. B. (2015). A business analytics capability framework. Australasian Journal of Information Systems, 19.

38. Cruz-Jesus, F., Oliveira, T., \& Naranjo, M. (2018, March). Understanding the adoption of business analytics and intelligence. In World Conference on Information Systems and Technologies (pp. 1094-1103). Springer, Cham.

39. Demirbag, M., Wood, G., Makhmadshoev, D., \& Rymkevich, O. (2017). Varieties of CSR: Institutions and socially responsible behaviour. International Business Review, 26(6), 1064-1074.

40. Demirkan, H., \& Delen, D. (2013). Leveraging the capabilities of service-oriented decision support systems: Putting analytics and big data in cloud. Decision Support Systems, 55(1), 412-421.

41. Dijkstra, T.K. and Henseler, J. (2015), "Consistent partial least squares path modeling”, MIS Quarterly, Vol. 39 No. 2, pp. 297-316

42. DiMaggio, P. J., \& Powell, W. W. (1983). The iron cage revisited: Institutional isomorphism and collective rationality in organizational fields. American sociological review, 147-160.

43. DiMaggio, P. J., \& Powell, W. W. (1983). The iron cage revisited: Institutional isomorphism and collective rationality in organizational fields. American sociological review, 147-160.

44. Dubey, R., Gunasekaran, A., Childe, S. J., Blome, C., \& Papadopoulos, T. (2019). Big data and predictive analytics and manufacturing performance: integrating institutional theory, resource-based view and big data culture. British Journal of Management, 30(2), 341-361.

45. Dumas, M., La Rosa, M., Mendling, J., \& Reijers, H. A. (2013). Business process management. Berlin: Springer-Verlag.

46. Elbashir, M. Z., Collier, P. A., \& Davern, M. J. (2008). Measuring the effects of business intelligence systems: The relationship between business process and organizational performance. International journal of accounting information systems, 9(3), 135-153.

47. Evans, J. R., \& Lindner, C. H. (2012). Business analytics: the next frontier for decision sciences. Decision Line, 43(2), 4-6.

48. Fornell, C.G. and Larcker, D.F. (1981), "Evaluating structural equation models with unobservable variables and measurement error", Journal of Marketing Research, Vol. 18 No. 1, pp. 39-50. 
49. Gago-Areces, M. (2017). Business Strategy in the Digital Age. Digital Transformation, Disruption and Cybersecurity. In Cyberspace (pp. 75-94). Springer, Cham.

50. Gaya, H., \& Struwig, M. (2016). Is Activity-Resource-based View (ARBV) the New Theory of the Firm for Creating Sources of Sustainable Competitive Advantage in Services Firms?. Global Journal of Management And Business Research.

51. Glover, J. L., Champion, D., Daniels, K. J., \& Dainty, A. J. (2014). An Institutional Theory perspective on sustainable practices across the dairy supply chain. International Journal of Production Economics, 152, 102111.

52. Greenwood, R., \& Hinings, C. R. (1996). Understanding radical organizational change: Bringing together the old and the new institutionalism. Academy of management review, 21(4), 1022-1054.

53. Gu, Q., Jitpaipoon, T., \& Yang, J. (2017). The impact of information integration on financial performance: A knowledge-based view. International Journal of Production Economics, 191, 221-232.

54. Gunasekaran, A., Papadopoulos, T., Dubey, R., Wamba, S. F., Childe, S. J., Hazen, B., \& Akter, S. (2017). Big data and predictive analytics for supply chain and organizational performance. Journal of Business Research, 70, 308-317.

55. Gunasekaran, A., T. Papadopoulos, R. Dubey, S. F. Wamba, S. J. Childe, B. Hazen and S. Akter (2016). 'Big data and predictive analytics for supply chain and organizational performance', Journal of Business Research, 70, pp. 308-317.

56. Gupta, M., \& George, J. F. (2016). Toward the development of a big data analytics capability. Information \& Management, 53(8), 1049-1064.

57. Hair, J.F., Hult, G.T.M., Ringle, C.M. and Sarstedt, M. (2017a), A Primer on Partial Least Squares Structural Equation Modeling (PLS-SEM), Sage, Thousand Oaks, CA.

58. Hair, J.F., Sarstedt, M. and Ringle, C.M. (2019), "Rethinking some of the rethinking of partial least squares", European Journal of Marketing, Forthcoming.

59. Hair, J.F., Sarstedt, M., Ringle, C.M. and Gudergan, S.P. (2018), Advanced Issues in Partial Least Squares Structural Equation Modeling (PLS-SEM), Sage, Thousand Oaks, CA.

60. Hazen, B. T., Boone, C. A., Ezell, J. D., \& Jones-Farmer, L. A. (2014). Data quality for data science, predictive analytics, and big data in supply chain management: An introduction to the problem and suggestions for research and applications. International Journal of Production Economics, 154, 72-80.

61. Henseler, J., Ringle, C.M. and Sarstedt, M. (2015), "A new criterion for assessing discriminant validity in variance-based structural equation modeling", Journal of the Academy of Marketing Science, Vol. 43 No. 1, pp. 115-135.

62. Hindle, G. A., \& Vidgen, R. (2018). Developing a business analytics methodology: A case study in the foodbank sector. European Journal of Operational Research, 268(3), 836-851.

63. Hitt, M. A., Ireland, R. D., \& Hoskisson, R. E. (2007). Strategic Management: Competitiveness and Globalization (7 ed.). Ohio: Thomson/South Western.

64. Hoejmose, S. U., Grosvold, J., \& Millington, A. (2014). The effect of institutional pressure on cooperative and coercive 'green'supply chain practices. Journal of Purchasing and Supply Management, 20(4), 215-224.

65. Holsapple, C., Lee-Post, A., \& Pakath, R. (2014). A unified foundation for business analytics. Decision Support Systems, 64, 130-141.

66. James, T., \& De Lourdes Machado, M. (2006). Higher Education Leadership and Management: From Conflict to Interdependence Through Strategic Planning. Tertiary Education and Management, 12, 137-160.

67. Jia, Z., Zhan, J., Wang, L., Luo, C., Gao, W., Jin, Y., ... \& Zhang, L. (2016). Understanding big data analytics workloads on modern processors. IEEE Transactions on Parallel and Distributed Systems, 28(6), 1797-1810.

68. Jooste, C., \& Fourie, B. (2009). The role of strategic leadership in effective strategy implementation: Perceptions of South African strategic leaders. Southern African Business Review, 13(3).

69. Judge, T. A., \& Piccolo, R. F. (2004). Transformational and transactional leadership: a meta-analytic test of their relative validity. Journal of applied psychology, 89(5), 755.

70. Ke, W., \& Wei, K. K. (2008). Organizational culture and leadership in ERP implementation. Decision Support Systems ELSEVIER, 45(2), 208-218.

71. Ketokivi, M.A., Schroeder, R.G., 2004. Strategic, structural contingency and institu- tional explanations in the adoption of innovative manufacturing practices. Journal of Operations Management 22 (1), 63-89.

72. Khan, Z., \& Vorley, T. (2017). Big data text analytics: an enabler of knowledge management. Journal Sumbal, M. S., Tsui, E., \& See-to, E.W. (2017). Interrelationship between big data and knowledge management: an exploratory study in the oil and gas sector. Journal of Knowledge Management.of Knowledge Management.

73. Kock, N. (2015). Common method bias in PLS-SEM: A full collinearity assessment approach. International Journal of e-Collaboration (ijec), 11(4), 1-10.

74. Kohavi, R., Rothleder, N. J., \& Simoudis, E. (2002). Emerging trends in business analytics. Communications of the $A C M, 45(8), 45-48$.

75. Kornacka, D. (2001). Social-strategic dimension of corporate success. In: Mark, S. Elements of corporate science, Szczecin University Fund, Szczecin. 
76. Lado, A. A., \& Wilson, M. C. (1994). Human resource systems and sustained competitive advantage: A competency-based perspective. Academy of management review, 19(4), 699-727.

77. Larson, D., \& Chang, V. (2016). A review and future direction of agile, business intelligence, analytics and data science. International Journal of Information Management, 36(5), 700-710.

78. Laudon, K., \& Laudon, J. P. (2013). Management information systems, global edition. Pearson Education UK.

79. Lavalle, S., Hopkins, M., Lesser, E., Shockley, R., \& Kruschwitz, N. (2010). Analytics: The new path to valueHow the smartest organizations are embedding analytics to transform insights into action. USA. IBM Institute for Business Value \& MIT Sloan Management Review, Executive Report.

80. Lee, J. (2008). Effects of leadership and leader-member exchange on innovativeness. Journal of managerial psychology.

81. Liberatore, M. J., \& Luo, W. (2010). The analytics movement: Implications for operations research. Interfaces, 40(4), 313-324.

82. Lin, R. J., \& Sheu, C. (2012). Why do firms adopt/implement green practices?-an institutional theory perspective. Procedia-Social and Behavioral Sciences, 57, 533-540.

83. Ling-Yee, L. (2007). 'The effects of firm resources on trade show performance: how do trade show marketing processes matter?', Journal of Business \& Industrial Marketing, 23,pp. 35-47.

84. Liu, H., Ke, W., Wei, K. K., Gu, J., \& Chen, H. (2010). The role of institutional pressures and organizational culture in the firm's intention to adopt internet-enabled supply chain management systems. Journal of Operations Management, 28(5), 372-384.

85. Liu, W., Yang, H., \& Zhang, G. (2012). Does family business excel in firm performance? An institution-based view. Asia Pacific Journal of Management, 29(4), 965-987.

86. Luo, J., Fan, M., \& Zhang, H. (2012). Information technology and organizational capabilities: A longitudinal study of the apparel industry. Decision Support Systems, 53(1), 186-194.

87. Luque, M. S., Washburn, N. T., Waldman, D. A., \& House, R. J. (2008). Unrequited Profit: How Stakeholder and Economic Values Relate to Subordinates' Perceptions of Leadership and Firm Performance. Administrative Science Quarterly, 626-654.

88. Mahmood, M. A., \& Soon, S. K. (1991). A comprehensive model for measuring the potential impact of information technology on organizational strategic variables. Decision Sciences, 22(4), 869-897.

89. McAfee, A., Brynjolfsson, E., Davenport, T. H., Patil, D. J., \& Barton, D. (2012). Big data: the management revolution. Harvard business review, 90(10), 60-68.

90. McCormack, K., Willems, J., Van den Bergh, J., Deschoolmeester, D., Willaert, P., Štemberger, M. I., ... \& Vlahovic, N. (2009). A global investigation of key turning points in business process maturity. Business Process Management Journal.

91. McLaren, T. S., Head, M. M., Yuan, Y., \& Chan, Y. E. (2011). A multilevel model for measuring fit between a firm's competitive strategies and information systems capabilities. Mis Quarterly, 909-929.

92. Mithas, S., Ramasubbu, N., \& Sambamurthy, V. (2011). How information management capability influences firm performance. MIS quarterly, 237-256.

93. Mithas, S., Ramasubbu, N., \& Sambamurthy, V. (2011). How information management capability influences firm performance. MIS quarterly, 237-256.

94. Mizruchi, M. S., \& Fein, L. C. (1999). The social construction of organizational knowledge: A study of the uses of coercive, mimetic, and normative isomorphism. Administrative science quarterly, 44(4), 653-683.

95. Montes, F. J. L., Moreno, A. R., \& Fernández, L. M. M. (2004). Assessing the organizational climate and contractual relationship for perceptions of support for innovation. International Journal of manpower.

96. Montgomery, C. A. (2008, January). Putting Leadershp Back into Strategy. Harvard Business Review, pp. 1-6.

97. Nair, A. K., \& Bhattacharyya, S. S. (2019). Mandatory corporate social responsibility in India and its effect on corporate financial performance: Perspectives from institutional theory and resource-based view. Business Strategy \& Development, 2(2), 106-116.

98. Nam, D., Lee, J., \& Lee, H. (2019). Business analytics adoption process: An innovation diffusion perspective. International Journal of Information Management, 49, 411-423.

99. Oliver, G. 1997. Sustainable competitive advantage: Gombining institutional and resource-based views. Strategic Management Journal, 18: 697-713.

100.Omar, Y. M., Minoufekr, M., \& Plapper, P. (2019). Business analytics in manufacturing: Current trends, challenges and pathway to market leadership. Operations Research Perspectives, 6, 100127.

101.Peng, M. W., Sun, S. L., Pinkham, B., \& Chen, H. (2009). The institution-based view as a third leg for a strategy tripod. Academy of Management Perspectives, 23(3), 63-81.

102.Peng, M.W. S. L. Sun, B. Pinkham and H. Chen (2009). 'The institution-based view as a third leg for a strategy tripod', Academy of Management Perspectives,23,pp. 63-81.

103.Podsakoff, P. M., MacKenzie, S. B., Lee, J. Y., \& Podsakoff, N. P. (2003). Common method biases in behavioral research: a critical review of the literature and recommended remedies. Journal of applied psychology, 88(5), 879. 
104.Pounder, J. S. (2008). Transformational leadership: Practicing what we teach in the management classroom. Journal of Education for Business, 84(1), 2-6.

105.Raguseo, E., \& Vitari, C. (2018). Investments in big data analytics and firm performance: an empirical investigation of direct and mediating effects. International Journal of Production Research, 56(15), 5206-5221.

106.Raguseo, E., \& Vitari, C. (2018). Investments in big data analytics and firm performance: an empirical investigation of direct and mediating effects. International Journal of Production Research, 56(15), 5206-5221.

107. Raguseo, E., Vitari, C., \& Pigni, F. (2020). Profiting from big data analytics: The moderating roles of industry concentration and firm size. International Journal of Production Economics, 107758.

108. Ramanathan, R., Philpott, E., Duan, Y., \& Cao, G. (2017). Adoption of business analytics and impact on performance: A qualitative study in retail. Production Planning and Control, 28(11-12), 985-998.

109. Rialti, R., Zollo, L., Ferraris, A., \& Alon, I. (2019). Big data analytics capabilities and performance: Evidence from a moderated multi-mediation model. Technological Forecasting and Social Change, 149, 119781.

110.Rigdon, E.E., Sarstedt, M. and Ringle, C.M. (2017), "On comparing results from CB-SEM and PLS-SEM. Five perspectives and five recommendations”, Marketing Zfp, Vol. 39 No. 3, pp. 4-16.

111.Robbins, S. P. (2003). Organizational behavior. Upper Saddle River, NJ: Pearson Education, Inc.

112. Robson, I. (2004). From process measurement to performance improvement. Business Process Management Journal.

113.Rubin, R. S., Munz, D. C., \& Bommer, W. H. (2005). LEADING FROM WITHIN: THE EFFECTS OF EMOTION RECOGNITION AND PERSONALITY ON TRANSFORMATIONAL LEADERSHIP BEHAVIOR. The Academy of Management Journal, 48(5), 845-858.

114.Saggi, M. K., \& Jain, S. (2018). A survey towards an integration of big data analytics to big insights for valuecreation. Information Processing \& Management, 54(5), 758-790.

115.Sarros, J. C., Cooper, B. K., \& Santora, J. C. (2008, November). Building a Climate for Innovation Through Transformational Leadership and Organizational Culture. Journal of Leadership \& Organizational Studies, 15(2), 145-158.

116.Sarros, J. C., Cooper, B. K., \& Santora, J. C. (2008, November). Building a Climate for Innovation Through Transformational Leadership and Organizational Culture. Journal of Leadership \& Organizational Studies, 15(2), 145-158.

117.Schein, E. H. (2004). Organizational culture and leadership Third edition.

118.Schuler, R. S., \& Jackson, S. E. (1995). Understanding human resource management in the context of organizations and their environment. Annual Review of Psychology, 46(1), 237-264.

119.Sharda, R., Delen, D., \& Turban, E. (2016). Business intelligence, analytics, and data science: a managerial perspective. Pearson.

120.Sharma, R., Mithas, S., \& Kankanhalli, A. (2014). Transforming decision-making processes: a research agenda for understanding the impact of business analytics on organisations.

121. Sharma, S., "Macroeconomic and predictive analytics based on toll-free number utilization." U.S. Patent 9,654,649, issued May 16, 2017.

122.Shmueli, G. (2010), “To explain or to predict?”, Statistical Science, Vol. 25 No. 3, pp. 289-310.

123.Shmueli, G., Ray, S., Velasquez Estrada, J.M. and Shatla, S.B. (2016), "The elephant in the room: evaluating the predictive performance of PLS models", Journal of Business Research, Vol. 69 No. 10, pp. 4552-4564.

124.Sirmon, D. G., Hitt, M. A., \& Ireland, R. D. (2007). Managing firm resources in dynamic environments to create value: Looking inside the black box. Academy of management review, 32(1), 273-292.

125.Sully de Luque, M., Washburn, N. T., Waldman, D. A., \& House, R. J. (2008, Dec). Unrequited Profit: How Stakeholder and Economic Values Relate to Subordinates'. Administrative Science Quarterly, 626-654.

126. Takahashi, A. R. W., \& Sander, J. A. (2017). Combining institutional theory with resource based theory to understand processes of organizational knowing and dynamic capabilities. European journal of management issues, (25,№ 1), 43-48.

127.Tan, F. T. C., Guo, Z., Cahalane, M., \& Cheng, D. (2016). Developing business analytic capabilities for combating e-commerce identity fraud: A study of Trustev's digital verification solution. Information \& Management, 53(7), 878-891.

128. Tate, W. L., Dooley, K. J., \& Ellram, L. M. (2011). Transaction cost and institutional drivers of supplier adoption of environmental practices. Journal of Business Logistics, 32(1), 6-16.

129.Tatoglu, E., Glaister, A. J., \& Demirbag, M. (2016). Talent management motives and practices in an emerging market: A comparison between MNEs and local firms. Journal of World Business, 51(2), 278-293.

130.Teo, H. H., Wei, K. K., \& Benbasat, I. (2003). Predicting intention to adopt interorganizational linkages: An institutional perspective. MIS quarterly, 19-49.

131.Troilo, M., Bouchet, A., Urban, T. L., \& Sutton, W. A. (2016). Perception, reality, and the adoption of business analytics: Evidence from North American professional sport organizations. Omega, 59, 72-83. 
132. Vaccaro, I. G., Jansen, J. J., Van Den Bosch, F. A., \& Volberda, H. W. (2012). Management innovation and leadership: The moderating role of organizational size. Journal of Management Studies, 49(1), 28-51.

133.Van Looy, A., \& Shafagatova, A. (2016). Business process performance measurement: a structured literature review of indicators, measures and metrics. SpringerPlus, 5(1), 1797.

134.Vidgen, R., Shaw, S., \& Grant, D. B. (2017). Management challenges in creating value from business analytics. European Journal of Operational Research, 261(2), 626-639.

135.Vitari, C., \& Raguseo, E. (2020). Big data analytics business value and firm performance: linking with environmental context. International Journal of Production Research, 58(18), 5456-5476.

136. Voss, C. A., Åhlström, P., \& Blackmon, K. (1997). Benchmarking and operational performance: some empirical results. International Journal of Operations \& Production Management.

137.Walker, K., \& Brown-Liburd, H. (2019). The emergence of data analytics in auditing: Perspectives from internal and external auditors through the lens of institutional theory. Working paper May.

138. Wamba, S. F., Akter, S., \& De Bourmont, M. (2019). Quality dominant logic in big data analytics and firm performance. Business Process Management Journal.

139. Wamba, S. F., Akter, S., \& De Bourmont, M. (2019). Quality dominant logic in big data analytics and firm performance. Business Process Management Journal.

140.Wamba, S. F., Gunasekaran, A., Akter, S., Ren, S. J. F., Dubey, R., \& Childe, S. J. (2017). Big data analytics and firm performance: Effects of dynamic capabilities. Journal of Business Research, 70, 356-365.

141. Watson, H. J., Annino, D. A., Wixom, B. H., Avery, K. L., \& Rutherford, M. (2001). Current practices in data warehousing. Information Systems Management, 18(1), 47-55.

142. Whitelock, V. (2018). Business analytics and firm performance: role of structured financial statement data. Journal of Business Analytics, 1(2), 81-92.

143.Wójcik, P. (2015). Exploring links between dynamic capabilities perspective and resource-based view: A literature overview. International Journal of Management and Economics, 45(1), 83-107.

144.Wu, F., Yeniyurt, S., Kim, D., \& Cavusgil, S. T. (2006). The impact of information technology on supply chain capabilities and firm performance: A resource-based view. Industrial Marketing Management, 35(4), 493-504.

145.Xenikou, A., \& Simosi, M. (2006). Organizational culture and transformational leadership as a predictor of business unit performance. Journal of Managerial Psychology, 21(6), 566-579.

146.Xenikou, A., \& Simosi, M. (2006). Organizational culture and transformational leadership as a predictor of business unit performance. Journal of Managerial Psychology, 21(6), 566-579.

147. Yang, Y., \& Konrad, A. M. (2011). Understanding diversity management practices: Implications of institutional theory and resource-based theory. Group \& Organization Management, 36(1), 6-38.

148. Yong, K. T., \& Pheng, L. S. (2008). Organizational culture and TQM implementation in construction firms in Singapore. Construction Management and Economics, 26(3), 237-248.

149.Zhang, X., \& Bartol, K. M. (2010). LINKING EMPOWERING LEADERSHIP AND EMPLOYEE CREATIVITY: THE INFLUENCE OF. Academy of Management Journal, 53(1), 107-128.

150.Zhang, X., \& Bartol, K. M. (2010). LINKING EMPOWERING LEADERSHIP AND EMPLOYEE CREATIVITY: THE INFLUENCE OF. Academy of Management Journal, 53(1), 107-128.

151.Zsidisin*, G. A., Melnyk, S. A., \& Ragatz, G. L. (2005). An institutional theory perspective of business continuity planning for purchasing and supply management. International journal of production research, 43(16), 3401-3420.

152.Zu, X., Robbins, T. L., \& Fredendall, L. D. (2010). Mapping the critical links between organizational culture and TQM/Six Sigma practices. International journal of production economics, 123(1), 86-106.

153.Zwass, V., \& Kendall, K. (1999). Structure and macro-level impacts of electronic commerce. Emerging Information Technologies: Improving Decisions, Cooperation, and Infrastructure, Sage, Beverly Hills, CA, 289315. 